Prepared in cooperation with the U.S. Department of the Army Environmental and Natural Resources Management Office of the U.S. Army Signal Center and Fort Gordon

\title{
Assessment of Hyporheic Zone, Flood-Plain, Soil-Gas, Soil, and Surface-Water Contamination at the McCoys Creek Chemical Training Area, Fort Gordon, Georgia, 2009-2010
}

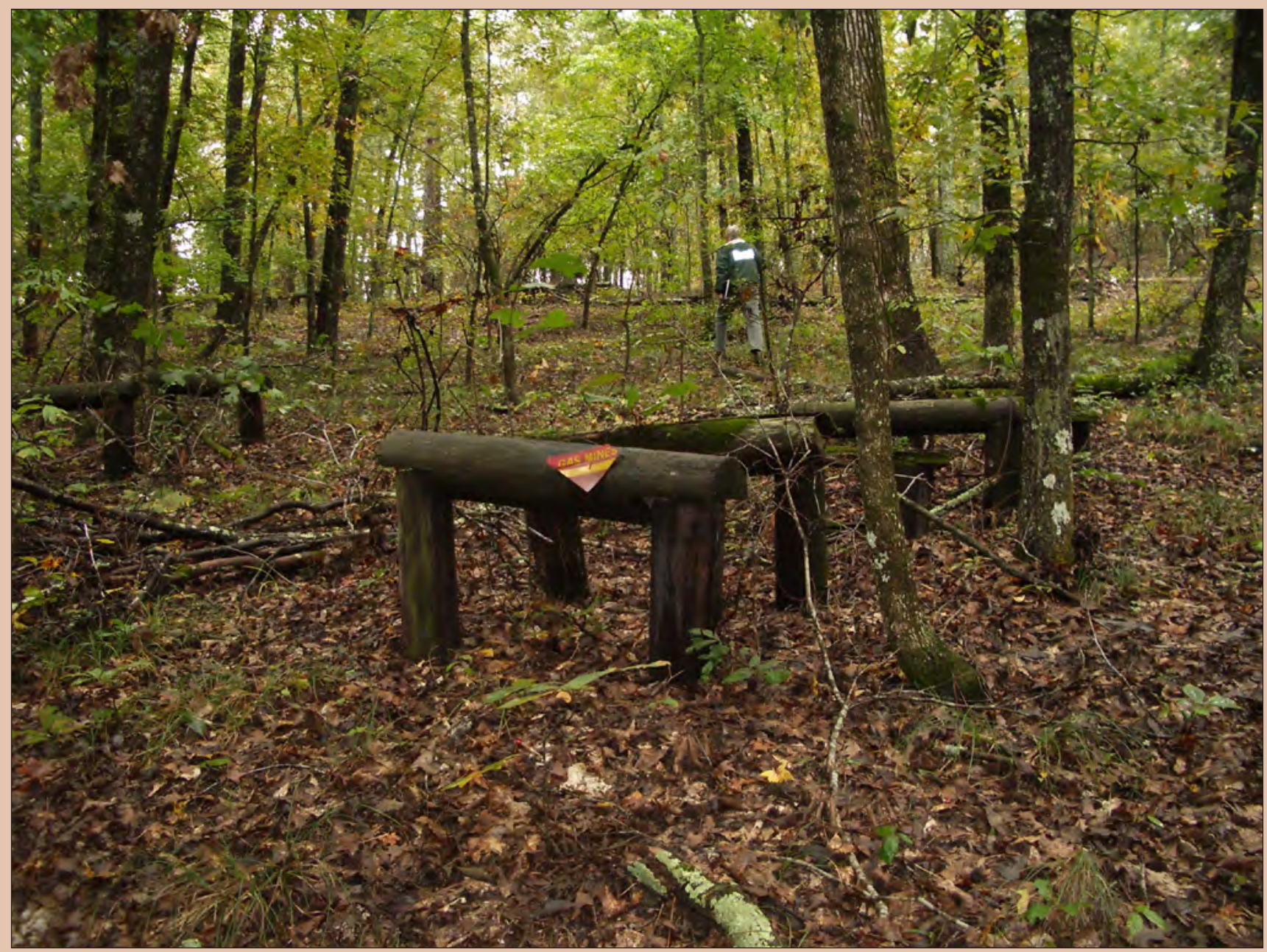

Open-File Report 2011-1267

U.S. Department of the Interior

U.S. Geological Survey 
Cover photograph. The McCoys Creek Chemical Training Area, Fort Gordon, Georgia, October 16, 2009 (W. Fred Falls, U.S. Geological Survey) 


\section{Assessment of Hyporheic Zone, Flood-Plain, Soil-Gas, Soil, and Surface-Water Contamination at the McCoys Creek Chemical Training Area, Fort Gordon, Georgia, 2009-2010}

By Wladmir B. Guimaraes, W. Fred Falls, Andral W. Caldwell, W. Hagan Ratliff, John B. Wellborn, and James E. Landmeyer

Prepared in cooperation with the U.S. Department of the Army Environmental and Natural

Resources Management Office of the U.S. Army Signal Center and Fort Gordon

Open-File Report 2011-1267 


\title{
U.S. Department of the Interior \\ KEN SALAZAR, Secretary \\ U.S. Geological Survey \\ Marcia K. McNutt, Director
}

\author{
U.S. Geological Survey, Reston, Virginia: 2011
}

For more information on the USGS - the Federal source for science about the Earth, its natural and living resources, natural hazards, and the environment, visit http://www.usgs.gov or call 1-888-ASK-USGS.

For an overview of USGS information products, including maps, imagery, and publications, visit http://www.usgs.gov/pubprod

To order this and other USGS information products, visit http://store.usgs.gov

Any use of trade, product, or firm names is for descriptive purposes only and does not imply endorsement by the U.S. Government.

Although this report is in the public domain, permission must be secured from the individual copyright owners to reproduce any copyrighted materials contained within this report.

Suggested citation:

Guimaraes, W.B, Falls, W.F., Caldwell, A.W., Ratliff, W.H., Wellborn, J.B., and Landmeyer, J.E., 2011, Assessment of hyporheic zone, flood-plain, soil-gas, soil, and surface-water contamination at the McCoys Creek Chemical Training Area, Fort Gordon, Georgia, 2009-2010: U.S. Geological Survey Open-File Report 2011-1267, 48 p. 


\section{Contents}

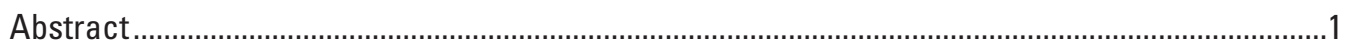

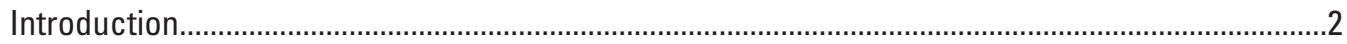

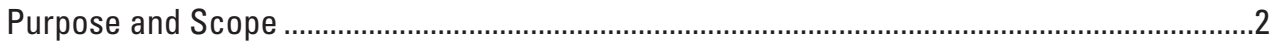

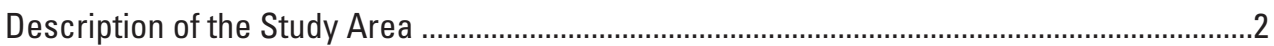

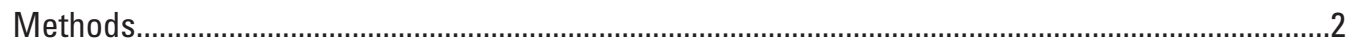

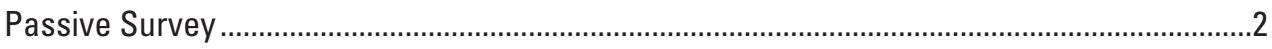

Passive Hyporheic Zone and Flood-Plain Survey ........................................................

Passive Soil-Gas Survey...................................................................................................

Explosives and Chemical Agents ...................................................................................

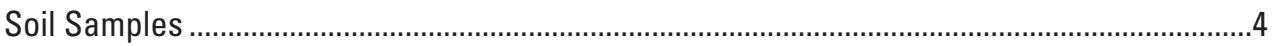

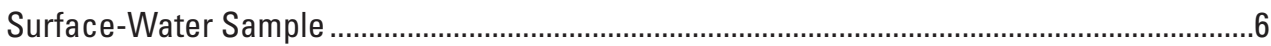

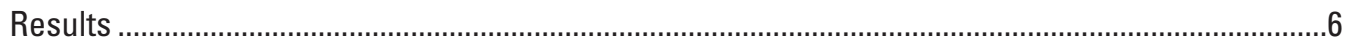

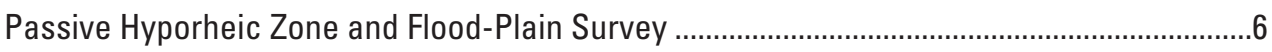

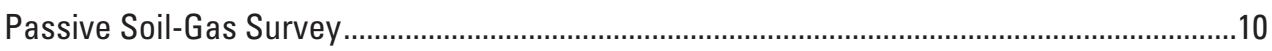

Explosives and Chemical Agents .....................................................................................

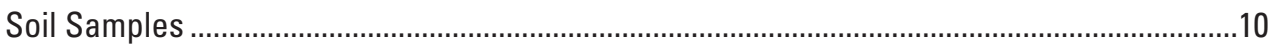

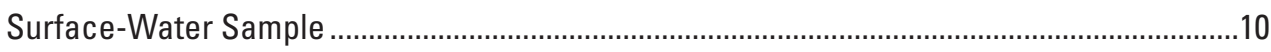

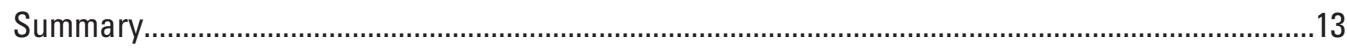

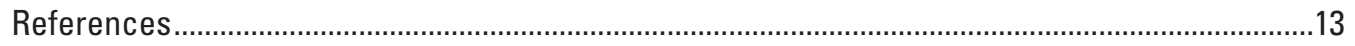

\section{Figures}

1. Map showing location of the McCoys Creek Chemical Training Area, Fort Gordon, Georgia

2. Photographs showing soil-gas sampler prior to being installed in a shallow borehole and following retrieval from a borehole and prior to shipping to laboratory for analysis

3. Map showing locations of hyporheic zone, flood-plain, and soil-gas sampling sites, McCoys Creek Chemical Training Area, Fort Gordon, Georgia, 2009-2010 ......................5

4. Photographs showing stainless-steel drive points prior to being deployed and after being deployed in the hyporheic zone of McCoys Creek, Fort Gordon, Georgia ...............6

5. Map showing locations of explosives and chemical agents, soil, and surface-water sampling sites, McCoys Creek Chemical Training Area, Fort Gordon, Georgia, 2009-2010

6. Map showing total petroleum hydrocarbon concentrations in the hyporheic zone and flood-plain samplers, McCoys Creek Chemical Training Area, Fort Gordon, Georgia, 2009-2010

7. Map showing octane concentrations in the hyporheic zone and flood-plain samplers, McCoys Creek Chemical Training Area, Fort Gordon, Georgia, 2009-2010

8. Map showing total petroleum hydrocarbons mass in soil-gas samplers, McCoys Creek Chemical Training Area, Fort Gordon, Georgia, 2009-2010

9. Map showing combined masses of benzene, toluene, ethylbenzene, and total xylenes in soil-gas samplers, McCoys Creek Chemical Training Area, Fort Gordon, Georgia, 2009-2010. 


\section{Tables}

1. Concentrations of organic compounds detected in the hyporheic zone and flood-plain samplers collected from McCoys Creek, McCoys Creek Chemical Training Area, Fort Gordon, Georgia, 2009-2010

2. Mass of organic compounds detected in soil-gas samplers, McCoys Creek Chemical Training Area, Fort Gordon, Georgia, 2009-2010.

3. Mass of explosives and chemical agents detected in soil-gas samplers, McCoys Creek Chemical Training Area, Fort Gordon, Georgia, 2009-2010....

4. Inorganic compounds detected in soil from land surface to 6 inches below land surface, site 1, McCoys Creek Chemical Training Area, Fort Gordon, Georgia, August 25, 2010.

5. Inorganic compounds detected in soil from land surface to 6 inches below land surface, site 2, McCoys Creek Chemical Training Area, Fort Gordon, Georgia, August 25, 2010

6. Inorganic compounds detected in soil from land surface to 6 inches below land surface, site 3, McCoys Creek Chemical Training Area, Fort Gordon, Georgia, August 25, 2010 .

7. Inorganic compounds detected in soil from land surface to 6 inches below land surface, site 4, McCoys Creek Chemical Training Area, Fort Gordon, Georgia, August 25, 2010 .

8. Inorganic compounds detected in soil from land surface to 6 inches below land surface, site 5, McCoys creek Chemical Training Area, Fort Gordon, Georgia, August 25, 2010.

9. Organic compounds detected in McCoys Creek, McCoys Creek Chemical Training Area, Fort Gordon, Georgia, September 8, 2010

10. Semivolatile organic compounds detected in McCoys Creek, McCoys Creek Chemical Training Area, Fort Gordon, Georgia, September 8, 2010

11. Inorganic compounds detected in McCoys Creek, McCoys Creek Chemical Training Area, Fort Gordon, Georgia, September 8, 2010 


\section{Conversion Factors and Datum}

\begin{tabular}{lcl}
\multicolumn{1}{c}{ Inch/Pound to SI } & & \\
\hline \multicolumn{1}{c}{ Multiply } & By & \multicolumn{1}{c}{ To obtain } \\
inch (in.) & Length & \\
inch (in.) & 2.54 & centimeter $(\mathrm{cm})$ \\
foot (ft) & 25.4 & millimeters $(\mathrm{mm})$ \\
mile (mi) & 0.3048 & meter (m) \\
\hline
\end{tabular}

Horizontal coordinate information is referenced to the North American Datum of 1983 (NAD 83).

\section{Acronyms and Abbreviations}

$\begin{array}{ll}\text { BTEX } & \text { Benzene, toluene, ethylbenzene, and xylene (total) } \\ \text { ISWQS } & \text { In-Stream Water-Quality Standard } \\ \text { MCTA } & \text { McCoys Creek Chemical Training Area } \\ \mathrm{mg} / \mathrm{kg} & \text { milligram per kilogram } \\ \mu \mathrm{g} & \text { microgram } \\ \mu \mathrm{g} / \mathrm{g} & \text { microgram per gram } \\ \mu \mathrm{g} / \mathrm{L} & \text { microgram per liter } \\ \mathrm{MCL} & \text { Maximum contaminant level } \\ \mathrm{MDL} & \text { Method detection level } \\ \text { MTBE } & \text { Methyl tert-butyl ether } \\ \text { NPDWS } & \text { National Primary Drinking Water Standard } \\ \text { NSDWS } & \text { National Secondary Drinking Water Standard } \\ \text { PAH } & \text { Polycyclic aromatic hydrocarbon } \\ \text { PCE } & \text { Perchloroethylene (also known as tetrachloroethylene) } \\ \text { RCRA } & \text { Resource Conservation and Recovery Act } \\ \text { RSL } & \text { Regional Screening Level } \\ \text { SCDHEC } & \text { South Carolina Department of Health and Environmental Control } \\ \text { SVOC } & \text { Semivolatile organic compounds } \\ \text { TCE } & \text { Trichloroethylene } \\ \text { TPH } & \text { Total Petroleum Hydrocarbons } \\ \text { USEPA } & \text { U.S. Environmental Protection Agency } \\ \text { VOC } & \text { Volatile organic compounds }\end{array}$





\title{
Assessment of Hyporheic Zone, Flood-Plain, Soil-Gas, Soil, and Surface Water Contamination at the McCoys Creek Chemical Training Area, Fort Gordon, Georgia, 2009-2010
}

\author{
By Wladmir B. Guimaraes, ${ }^{1}$ W. Fred Falls, ${ }^{1}$ Andral W. Caldwell, ${ }^{1}$ W. Hagan Ratliff, ${ }^{2}$ John B. Wellborn, ${ }^{3}$ \\ and James E. Landmeyer ${ }^{1}$
}

\section{Abstract}

The U.S. Geological Survey, in cooperation with the U.S. Department of the Army Environmental and Natural Resources Management Office of the U.S. Army Signal Center and Fort Gordon, Georgia, assessed the hyporheic zone, flood plain, soil gas, soil, and surface water for contaminants at the McCoys Creek Chemical Training Area (MCTA) at Fort Gordon, from October 2009 to September 2010. The assessment included the detection of organic contaminants in the hyporheic zone, flood plain, soil gas, and surface water. In addition, the organic contaminant assessment included the analysis of organic compounds classified as explosives and chemical agents in selected areas. Inorganic contaminants were assessed in soil and surface-water samples. The assessment was conducted to provide environmental contamination data to the U.S. Army at Fort Gordon pursuant to requirements of the Resource Conservation and Recovery Act Part B Hazardous Waste Permit process.

Ten passive samplers were deployed in the hyporheic zone and flood plain, and total petroleum hydrocarbons (TPH) and octane were detected above the method detection level in every sampler. Other organic compounds detected above the method detection level in the hyporheic zone and floodplain samplers were trichloroethylene, and cis- and trans1, 2-dichloroethylene. One trip blank detected TPH below the method detection level but above the nondetection level. The concentrations of TPH in the samplers were many times greater than the concentrations detected in the blank; therefore, all other TPH concentrations detected are considered to represent environmental conditions.

\footnotetext{
${ }^{1}$ U.S. Geological Survey, Columbia, South Carolina.

${ }^{2}$ Environmental Branch, Fort Gordon, Georgia.

${ }^{3}$ Environmental and Natural Resources, Fort Gordon, Georgia.
}

Seventy-one soil-gas samplers were deployed in a grid pattern across the MCTA. Three trip blanks and three method blanks were used and not deployed, and TPH was detected above the method detection level in two trip blanks and one method blank. Detection of TPH was observed at all 71 samplers, but because TPH was detected in the trip and method blanks, TPH was censored and, therefore, only 7 of the 71 samplers were reported as detecting TPH. In addition, benzene, toluene, ethylbenzene, and total xylene were detected above the method detection level in 22 samplers. Other compounds detected above the method detection level included naphthalene, octane, undecane, tridecane, 1,2,4-trimethylbenzene, trichloroethylene, perchloroethylene, chloroform, and 1,4-dichlorobenzene.

Subsequent to the soil-gas survey, five locations with elevated contaminant mass were selected and a passive sampler was deployed at those locations to detect the presence of organic compounds classified as explosives or chemical agents. No explosives or chemical agents were detected above the method detection level, but some compounds were detected below the method detection level but above the nondetection level. Dimethyl disulfide, benzothiazole, chloroacetophenones, and para-chlorophenyl methyl sulfide were all detected below the method detection level but above the nondetection level. The compounds 2,4-dinitrotoluene, and para-chlorophenyl methyl sulfone were detected in samplers but also were detected in trip blanks and are not considered as present in the MCTA.

The same five locations that were selected for sampling of explosives and chemical agents were selected for soil sampling. Metal concentrations in composite soil samples collected at five locations from land surface to a depth of 6 inches did not exceed the U.S. Environmental Protection Agency Regional Screening Levels for Industrial Soil. Concentrations in some compounds were higher than the South Carolina Department of Health and Environmental Control background levels for nearby South Carolina, including aluminum, arsenic, 
barium, beryllium, chromium, copper, iron, lead, manganese, nickel, and potassium.

A surface-water sample was collected from McCoys Creek and analyzed for volatile organic compounds, semivolatile organic compounds, and inorganic compounds (metals). No volatile organic compounds and (or) semivolatile organic compounds were detected at levels above the maximum contaminant level of the U.S. Environmental Protection Agency (USEPA) National Primary Drinking Water Standard, and no inorganic compounds exceeded the maximum contaminant level of the USEPA National Primary Drinking Water Standard or the Georgia In-Stream Water-Quality Standard. Iron was the only inorganic compound detected in the surface-water sample (578 micrograms per liter) that exceeded the USEPA National Secondary Drinking Water Standard of 300 micrograms per liter.

\section{Introduction}

Fort Gordon is a U.S. Department of the Army facility located in east-central Georgia, approximately 10 miles (mi) southwest of Augusta, Georgia (fig. 1). A cantonment (military housing) area is located at the northwestern boundary of Fort Gordon. Chemical warfare training was conducted in the southwestern part of the cantonment area near Lane Avenue. The McCoys Creek Chemical Training Area (MCTA) is located on a steeply sloping wooded area downstream from Wilkerson Lake and adjacent to McCoys Creek (fig. 1). Historically, little information is available for the MCTA except that chemical warfare training was taught at the location (Hagan Ratliff, Applied Services and Informational Systems, Inc., Installation Restoration Program Manager, oral commun., November 6, 2009). Presently (2011) some physical evidence of the training activities at the MCTA still exists, but no information is available about these activities. The potential exists for environmental contamination of the soil, groundwater, and surface water at or near the site; thus, a site-wide investigation is warranted. Additionally, the MCTA is located in the outcrop area for the Cretaceous-age aquifer system (Dublin and Midville), which is used for drinking water farther downgradient from the site (Williams, 2007). Surface water and groundwater from the MCTA site may discharge to McCoys Creek, which may enable potential contaminants to be transported beyond the boundaries of the Fort Gordon property.

\section{Purpose and Scope}

The purpose of this report is to provide the results of the analyses of samples collected by the U.S. Geological Survey, in cooperation with the U.S. Department of the Army Environmental and Natural Resources Management Office of the U.S. Army Signal Center and Fort Gordon, to assess the hyporheic zone, flood plain, soil gas, soil, and surface water at the MCTA at Fort Gordon, Georgia, from October 2009 to September 2010. The environmental assessment was conducted to provide contamination data to the U.S. Army at Fort Gordon. The assessment included passive samplers deployed in the hyporheic zone, flood plain, and soil in a grid pattern over the generalized extent of the MCTA to determine the presence of organic contaminants, explosives, and chemical agents from the MCTA. The presence of inorganic compounds was determined from the soil and surface-water samples. The report presents the analytical results for a total of 92 sites.

\section{Description of the Study Area}

Fort Gordon is a U.S. Army facility located in eastcentral Georgia, approximately $10 \mathrm{mi}$ southwest of Augusta, Georgia (fig. 1). Fort Gordon lies in the northern part of the Coastal Plain Physiographic Province and south of the Fall Line. Surficial soil and sediments are characterized by unconsolidated sands, indurated sands and semiconsolidated sandstones, and layers of clay that include kaolinite (Gregory and others, 2001).

\section{Methods}

All samples were collected in February, June, August, and September 2010 and were analyzed using standard laboratory practices (U.S. Geological Survey, variously dated). These methods were selected to provide data to determine the presence or absence of contamination in the hyporheic zone, flood plain, soil gas, soil, and surface water at the MCTA.

\section{Passive Survey}

The passive survey was conducted by using the GORETM Module, a commercially available passive diffusion sampler based on GORE-TEX ${ }^{\circledR}$ membrane technology (U.S. Environmental Protection Agency, 1998; W.L. Gore and Associates, Inc., 2004; American Society for Testing and Materials, 2006). The module consisted of an adsorbent material placed inside a shoestring-shaped GORE-TEX $®$ tube (fig. $2 A$ ). The adsorbent material can adsorb a wide variety of volatile organic compounds (VOC), including solvents such as perchloroethylene (PCE; also known as tetrachloroethylene); trichloroethylene (TCE); benzene, toluene, ethylbenzene, and total xylenes (collectively referred to as BTEX); methyl tert-butyl ether (MTBE); semivolatile organic compounds (SVOC); total petroleum hydrocarbons (TPH); and polycyclic aromatic hydrocarbons (PAH) such as naphthalene. The modules were deployed into the area of interest and then removed after a specified time period. For the hyporheic zone and flood-plain samples, the modules were inserted in water, which was just below the sediments. For soil-gas and explosives and chemical agent surveys, the modules were tied to a string, attached to a 

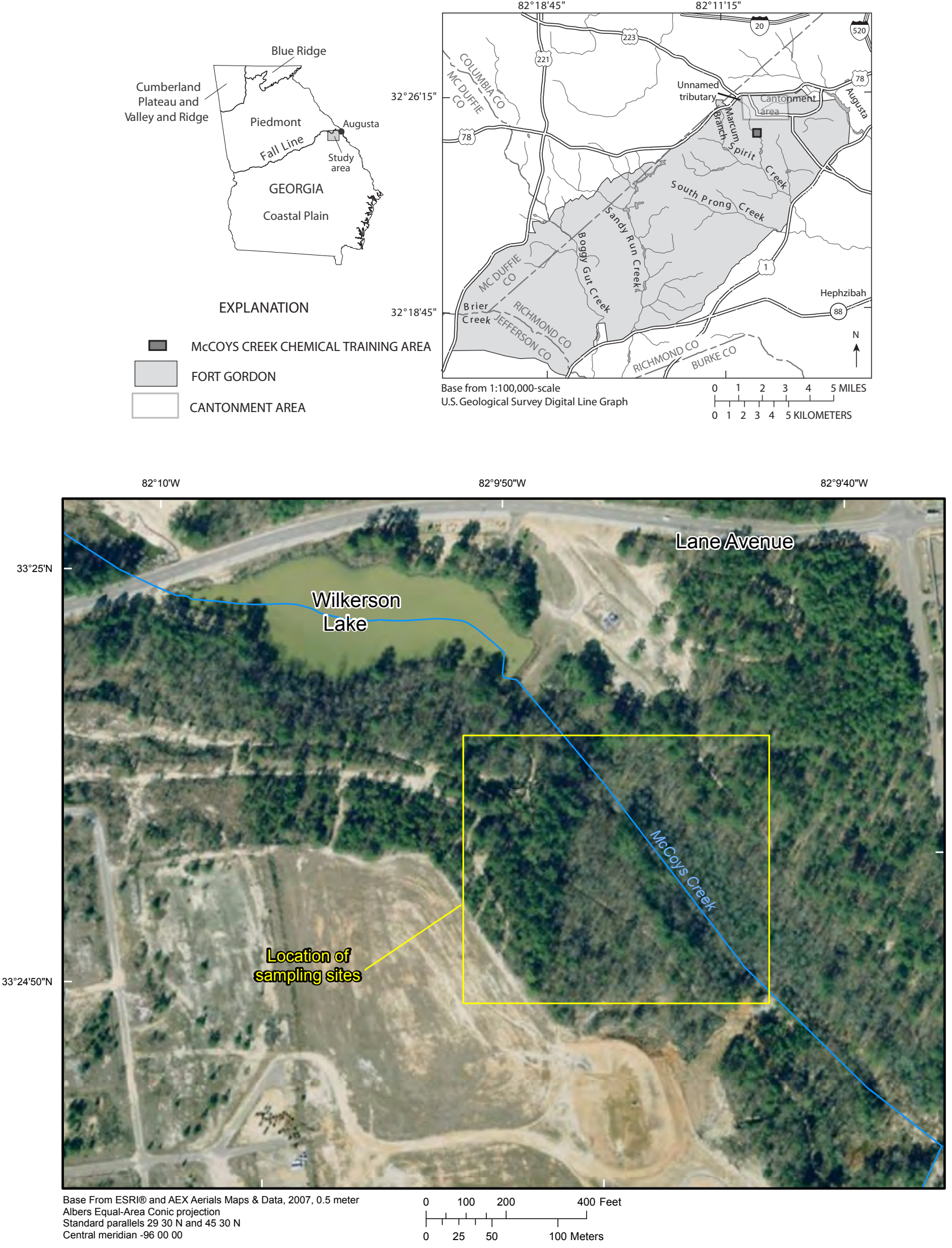

Figure 1. Location of the McCoys Creek Chemical Training Area, Fort Gordon, Georgia. 

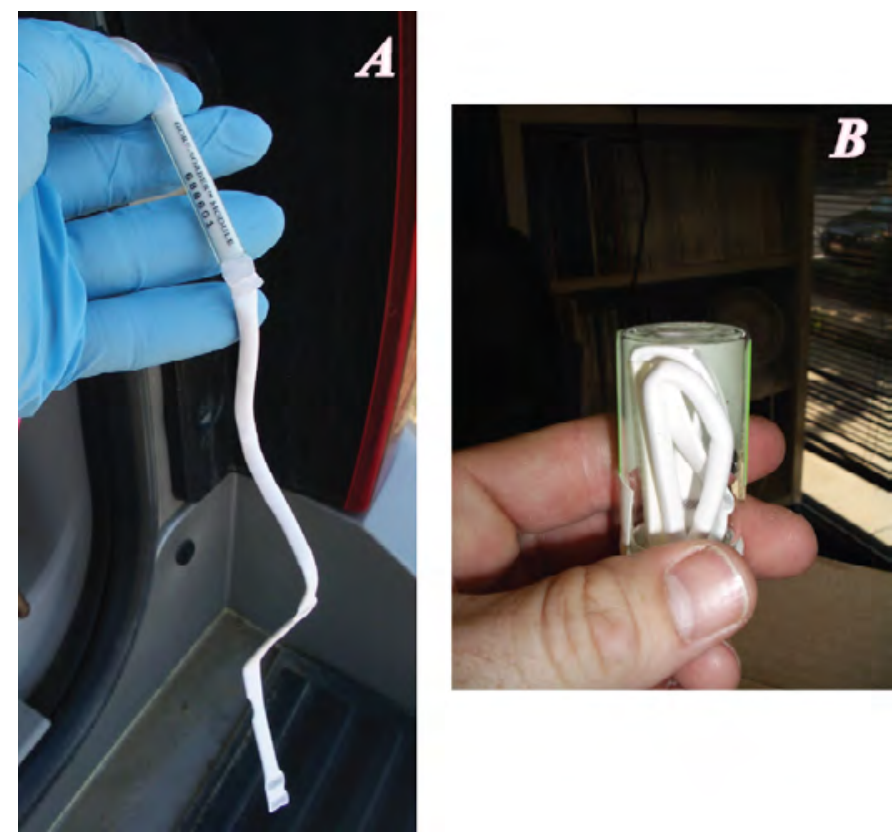

Figure 2. The soil-gas sampler $(A)$ prior to being installed in a shallow borehole and $(B)$ following retrieval from a borehole and prior to shipping to laboratory for analysis.

cork plug to prevent the entrance of surface water and ambient surface sources of contamination, inserted into a shallow borehole, and later removed from the field. After the modules were removed, whether placed in water or soil, they were placed in their original 20 -milliliter $(\mathrm{mL})$ gas-tight vials (fig. $2 B$ ) and sent to a commercial laboratory (W.L. Gore and Associates, Inc.) for analysis by gas chromatography/mass spectrometry using a modification of U.S. Environmental Protection Agency (USEPA) method 8260/8270 to include thermal desorption of the adsorbed soil gas from the sampler. The laboratory is in compliance with Good Laboratory Practices and ISO Guide 25 (International Organization for Standardization, 1990).

\section{Passive Hyporheic Zone and Flood-Plain Survey}

Ten modules were installed in the hyporheic zone and (or) flood-plain sediments from McCoys Creek located to the east of and downgradient from the MCTA on February 25, 2010 (fig. 3). Three additional samplers were used as trip blanks, and one sampler was used as a method blank, but these samplers were not deployed. The modules were deployed inside stainless-steel drive points with screened openings that allowed the drive point to act as a well (fig. $4 A$ ). Because the water inside the drive points (well) was groundwater, the samplers were exposed to groundwater contamination. The drive points provide passive sampling of the groundwater without installing a conventional monitoring well. The drive points were installed by hand no more than 1 foot ( $\mathrm{ft}$ ) into the hyporheic zone or flood-plain sediments (fig. 4B). Because the module was placed in water, the retrieval time was between
1 and 4 hours. The results of the passive hyporheic-zone and flood-plain survey are expressed in concentrations of contaminant in micrograms per liter.

\section{Passive Soil-Gas Survey}

Seventy-one modules were deployed in a grid pattern to cover the generalized extent of the MCTA (fig. 3). Three additional samplers were used as trip blanks, and three samplers were used as method blanks; these samplers were not deployed. Each sampler was placed in a borehole that was 0.5 inches (in.) in diameter, 15 in. deep, and created by a stainless-steel ship auger attached to a cordless drill. This depth is similar to what is recommended by the USEPA for soil-gas investigations (U.S. Environmental Protection Agency, 1998). The auger was cleaned with a paper towel prior to drilling of each borehole. The 71 modules were installed on June 9, 2010, and were removed on June 15, 2010. The soil-gas contaminant results are expressed as mass of contaminant in micrograms.

\section{Explosives and Chemical Agents}

Subsequent to the results of the passive soil-gas survey, five locations with elevated contaminant mass were selected as sampling sites for organic compounds classified as explosives and chemical agents (fig. 5). On September 15, 2010, five modules were deployed in the MCTA at those selected locations and removed on September 22, 2010. These modules were installed and retrieved as previously described in the passive survey section of this report, and analyzed for organic compounds classified as explosives and chemical agents. The results of the passive survey for explosives and chemical agents are expressed in mass of contaminant in micrograms.

\section{Soil Samples}

Soil samples were collected at the same five locations that were sampled for the explosives and chemical agents. Composite soil samples were collected on August 30, 2010, from land surface to 6 in. below land surface at the five locations (fig. 5). The samples were analyzed for 37 metals, including 6 of the 8 Resource Conservation Recovery Act (RCRA) metals (selenium and mercury were excluded). Soil-sample metal concentrations were compared to the USEPA Regional Screening Levels (RSL) for Industrial Soils (U.S. Environmental Protection Agency, 2009a) to determine the extent of contamination. Soil-sample metal concentrations also were compared to values for ambient, uncontaminated (background) levels for soils across the adjacent State of South Carolina (South Carolina Department of Health and Environmental Control, 2002), because no similar values were available for Georgia. The comparison remains valid, because Georgia and South Carolina are located in similar physiographic provinces. Soil samples were analyzed using methods described by Briggs and Meier (2002). 


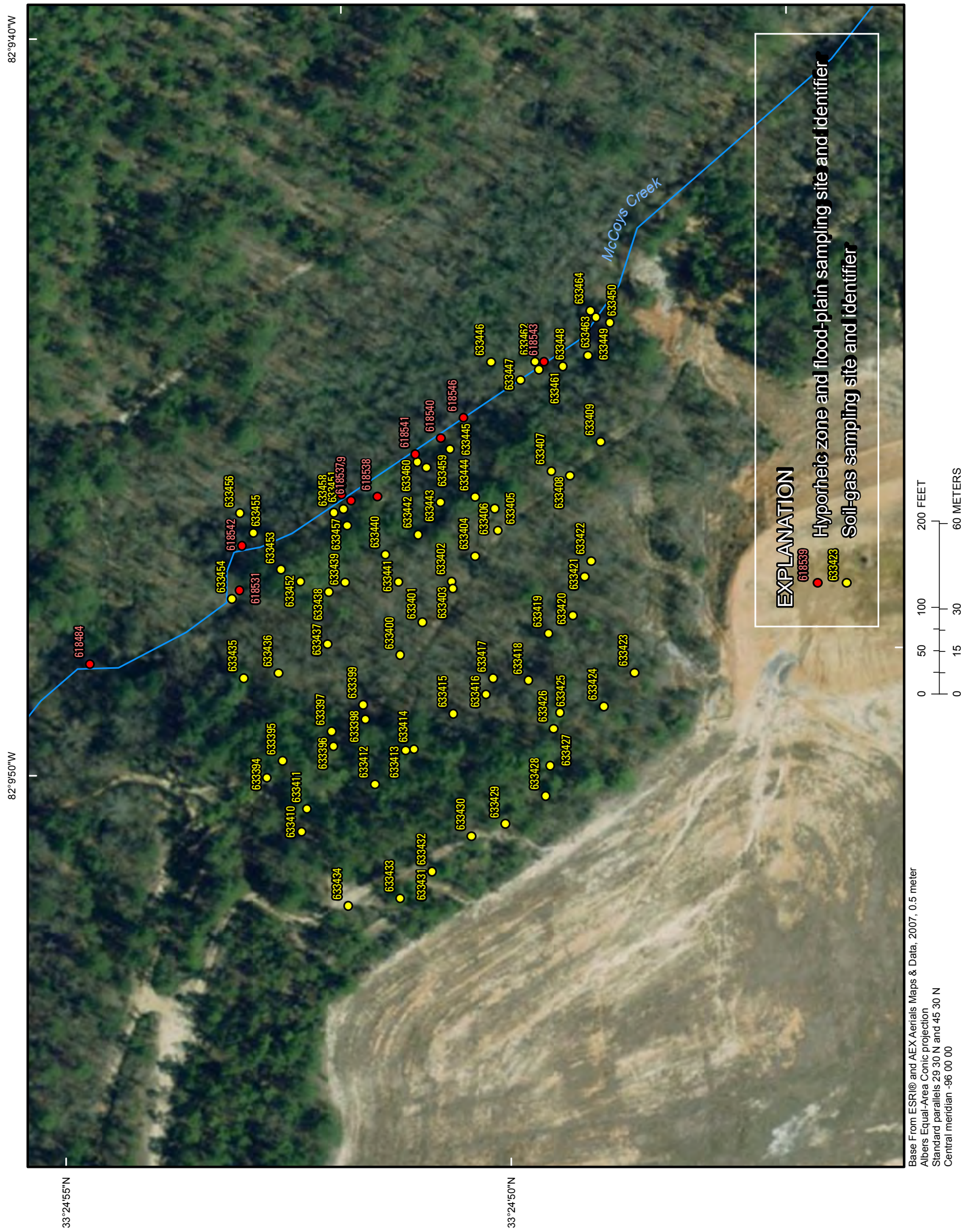



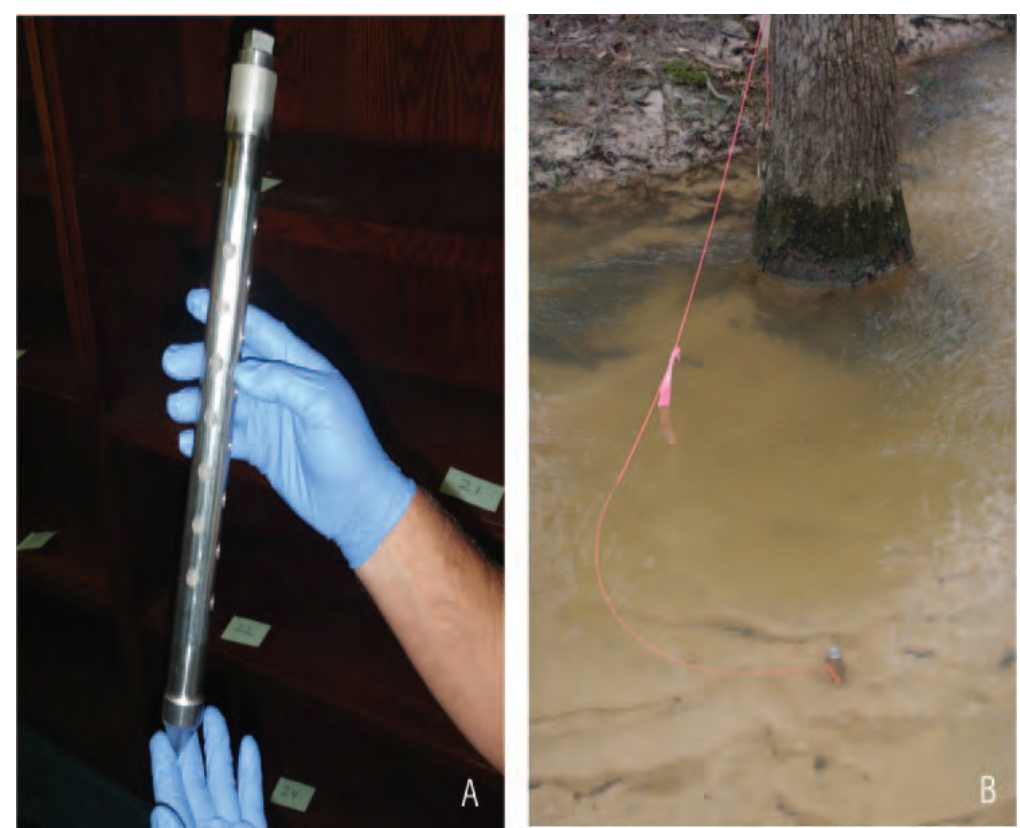

Figure 4. Stainless-steel drive points $(A)$ prior to being deployed and $(B)$ after being deployed in the hyporheic zone of McCoys Creek, Fort Gordon, Georgia.

\section{Surface-Water Sample}

A surface-water sample was collected on September 8, 2010, from McCoys Creek to the east of and downgradient from the MCTA (fig. 5). The water sample was collected after the results of the passive soil-gas survey were received. The surface-water sample represents the discharge of locally recharged groundwater or runoff that may have been in contact with the material beneath or at land surface of the MCTA. The water sample was analyzed for 85 VOCs, using methods described by Connor and others (1997), and 56 SVOCs (including PAHs), using methods described by Fishman (1993). The water sample also was analyzed for inorganic compounds (metals) by using methods described by Fishman and Friedman (1989), Hoffman and others (1996), Garbarino and Struzeski (1998), Garbarino and Damrau (2001), and Garbarino and others (2006). Inorganic compounds that were analyzed included seven of the eight RCRA metals (mercury was excluded). The water sample was analyzed using VOC and SVOC analytical methods. Seven compounds were determined using both methods and include naphthalene, 1,2-dichlorobenzene, 1,3-dichlorobenzene, 1,4-dichlorobenzene, 1,2,4-trichlorobenzene, hexachloroethane, and hexachlorobutadiene. The VOCs and SVOCs were compared to the maximum contaminant level (MCL) set by the USEPA National Primary Drinking Water Standard (NPDWS; U.S. Environmental Protection Agency, 2009b). The inorganic compounds (metals) were compared to the USEPA NPDWS, National Secondary Drinking Water Standard (NSDWS; U.S. Environmental Protection Agency, 2009b), and the
Georgia In-Stream Water-Quality Standard (ISWQS; Georgia Environmental Protection Division, 2005).

Handling censored data appropriately is necessary when laboratories report quantitative, estimated, and censored results. The results above a laboratory report level (LRL) are reported as a quantitative value, the results below the LRL and above the nondetection level is estimated (because the values are considered semiquantitative) and are reported with the remark code (E), and the results below the nondetection level are reported as censored data and will be reported as less than the LRL (Childress and others, 1999).

\section{Results}

The results of the multiple passive surveys and soil and water samples are presented in this section of the report. Passive survey results can indicate the presence of particular contaminants. The results do not, however, reveal if the detection is derived from a free product, a residual-phase adsorbed material or vapors in the unsaturated zone, or the dissolved-phase in shallow and deep groundwater (unless the module was placed in water). In general, higher mass in a sample tends to be related to the presence of residual contamination or free product that is close to land surface where the sampler is located. If the source material is located at greater depths, however, the contaminant mass will generally be lower. A lower value near known sources of contaminants can be caused by various attenuation processes that affect the mass prior to detection. In both cases, the modules help to rapidly indicate the presence or absence of contaminants. The passive approach was approved for use at the MCTA site by the Hazardous Waste Management Branch, Georgia Environmental Protection Department (William Powell, P.E., Environmental Engineer, Department of Defense Remediation Unit, oral commun., December 10, 2008). All results are from the raw data and are not filtered; therefore, the total mass or concentration of the constituent is reported.

\section{Passive Hyporheic Zone and Flood-Plain Survey}

All 10 passive samplers deployed in the hyporheic zone and (or) flood plain of the stream detected TPH concentrations greater than the method detection level (MDL) of 2.32 microgram per liter ( $\mu \mathrm{g} / \mathrm{L}$; table 1; fig. 6). Octane also was detected above the MDL of $1.16 \mu \mathrm{g} / \mathrm{L}$ at all samplers (table 1; fig. 7). The TPH concentrations ranged from 49.45 to $110.88 \mu \mathrm{g} / \mathrm{L}$, and octane ranged from 1.75 to $3.42 \mu \mathrm{g} / \mathrm{L}$. The only other VOCs detected were TCE at sampler numbers 618531 and 618539 and cis- and trans-1,2-dichloroethene at sampler number 618531. Pentadecane was detected below the MDL but above the nondetection level, and one of the trip blanks also detected pentadecane below the MDL and above the 


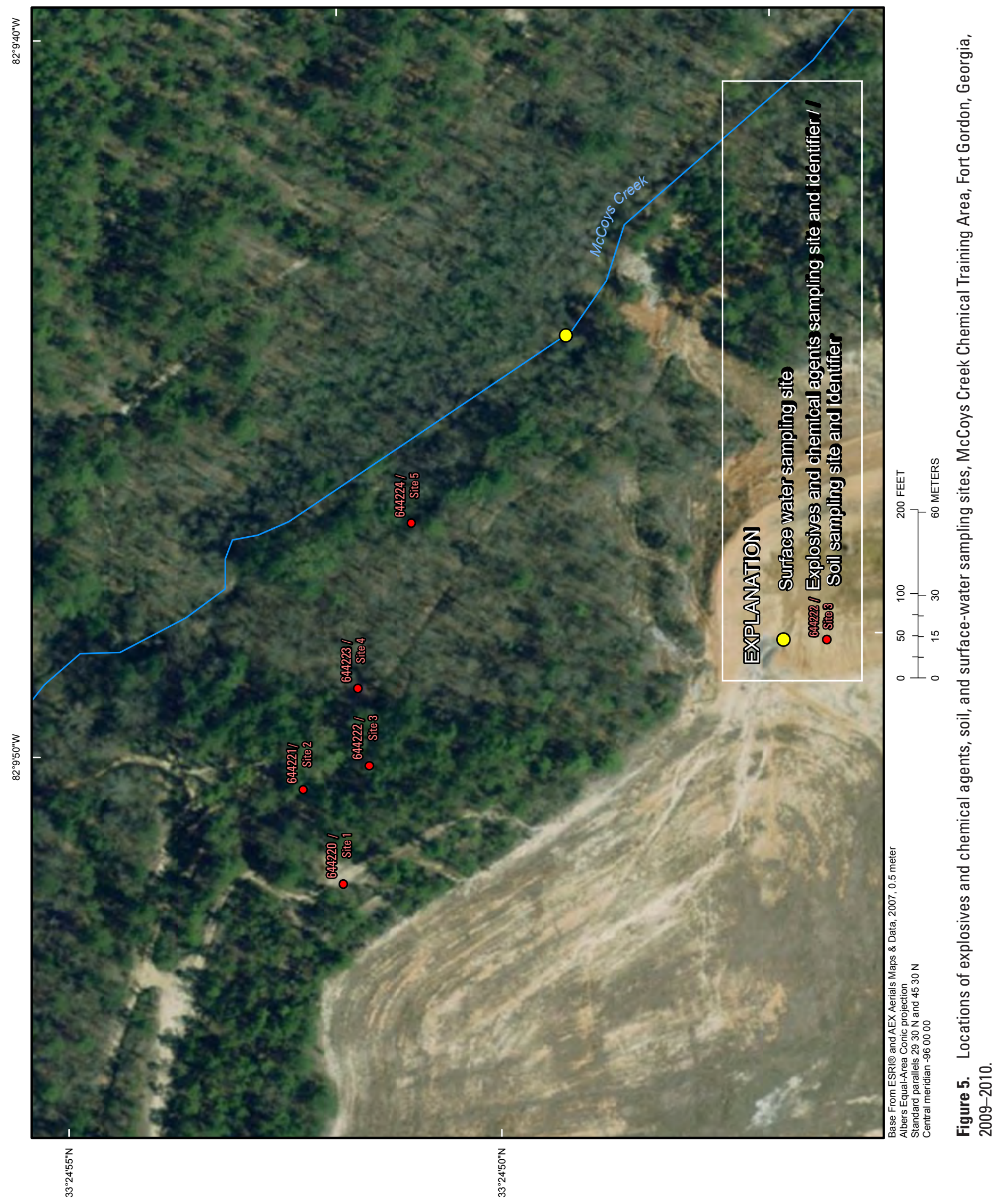




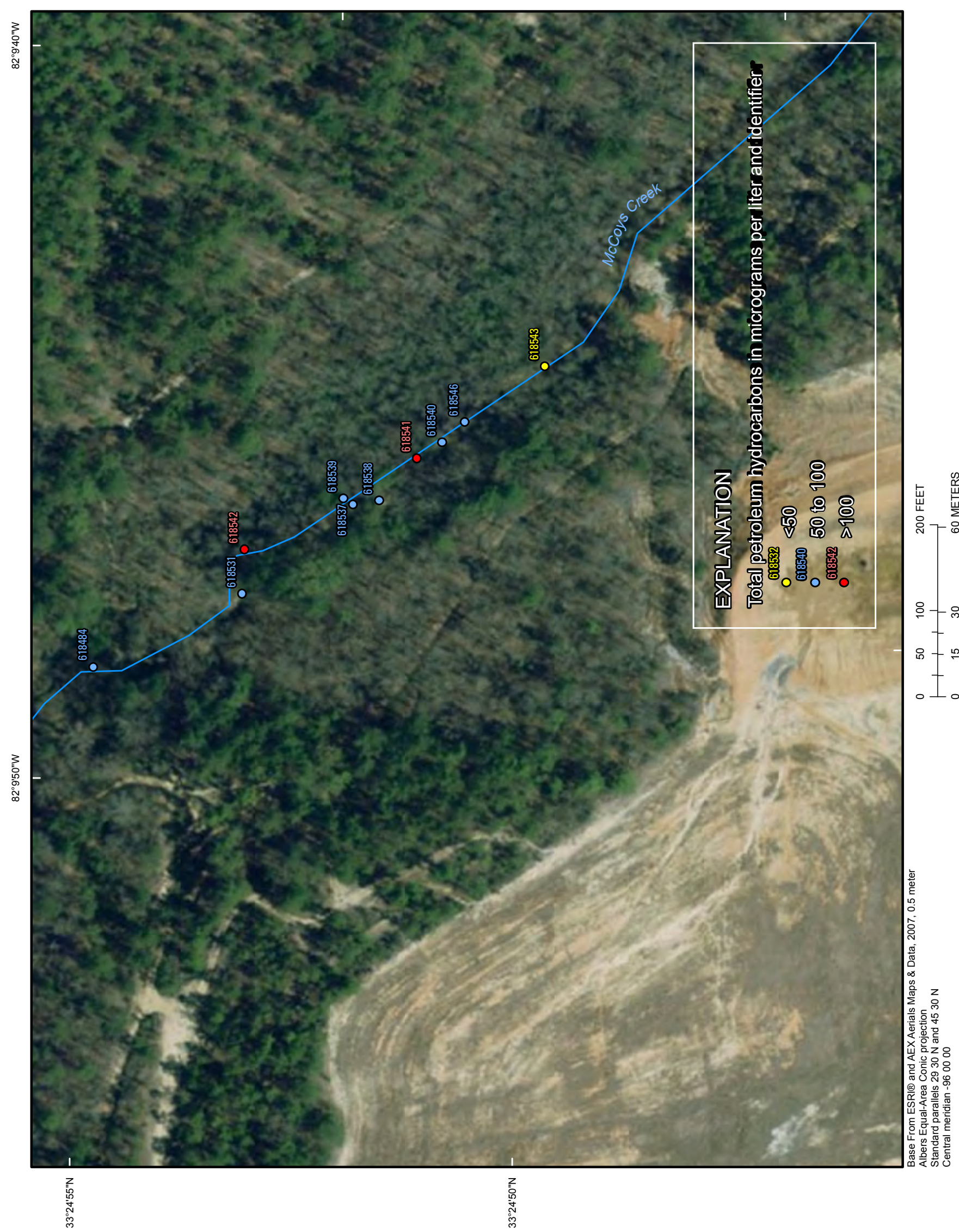




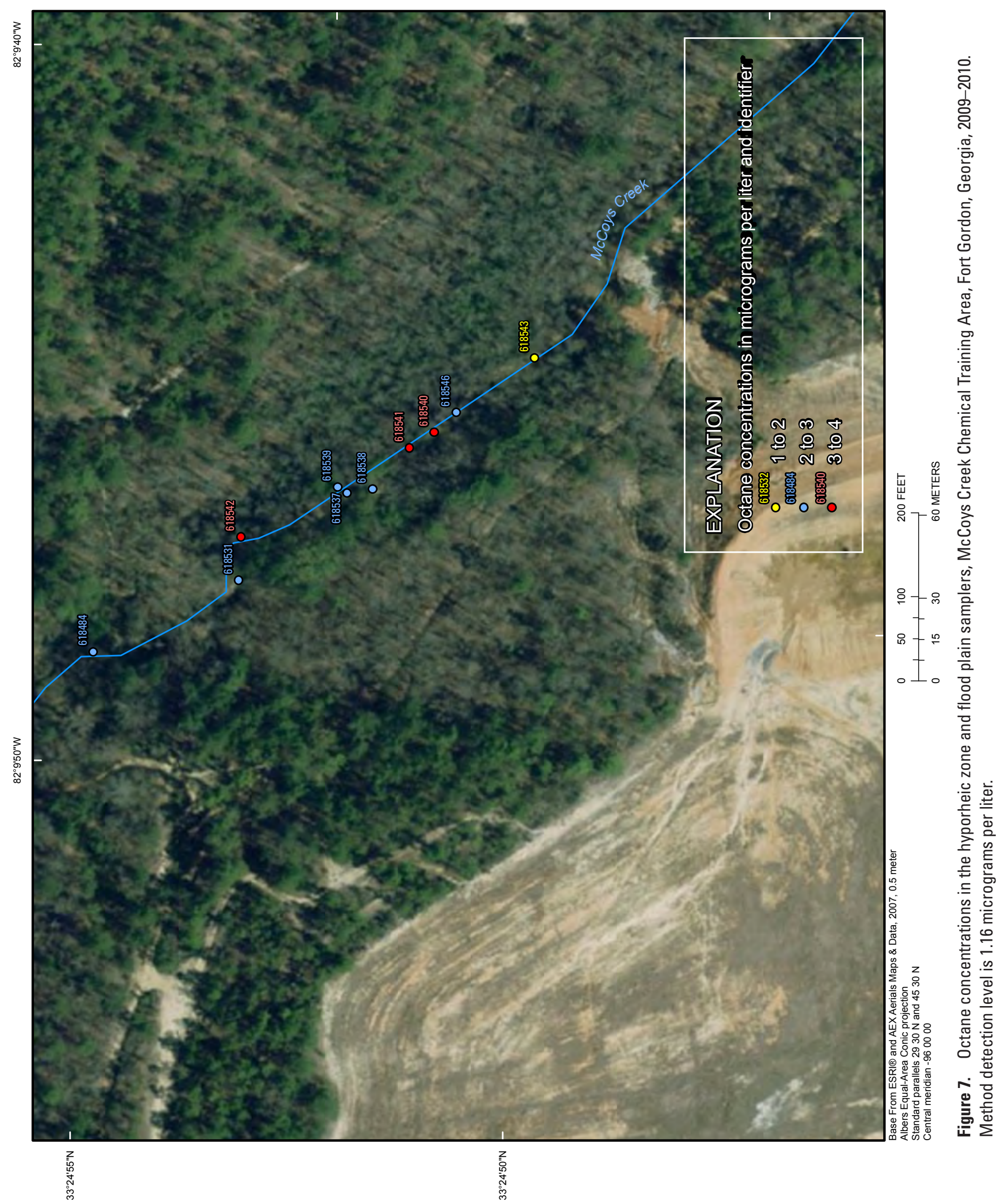


nondetection level; therefore, pentadecane probably was not present in the sample. No other volatile organic compounds were detected in the stream and (or) flood plain. Additionally, one of the field blanks detected TPH at a concentration below the MDL but above the nondetection level (table 1). TPH concentrations in the samplers were many times greater than the concentrations detected in the trip blanks; therefore, the results of TPH concentrations are considered to represent environmental conditions.

\section{Passive Soil-Gas Survey}

All soil-gas samplers deployed at the MCTA detected TPH mass greater than the MDL of 0.02 microgram $(\mu \mathrm{g}$; fig. 8; table 2). The highest soil-gas TPH mass was $90.75 \mu \mathrm{g}$ and was located in sampler number 633413. Soil-gas TPH mass ranged from $0.3 \mu \mathrm{g}$ to $90.75 \mu \mathrm{g}$, but TPH in the trip blanks ranged from below detection level to $2.72 \mu \mathrm{g}$, and one of the three method blanks detected a mass of $0.84 \mu \mathrm{g}$. The specific reason for the detection of TPH in the trip blanks and method blanks could not be identified, and the results of the hyporheic zone and flood-plain survey detected no TPH above the MDL in any of the trip or method (laboratory) blanks. Therefore, results for the soil-gas survey of TPH were censored at $27.2 \mu \mathrm{g}$ because, generally, if the mass in the blank(s) is less than 10 percent of the mass in the environmental sample(s), the effect of the contamination is likely to be within the precision of the method (U.S. Geological Survey, 1997) and not included in figure 8; results, however, are presented in table 2 as they were received from the laboratory. The censoring of the data shows that 7 of the 71 samplers detected TPH above $27.7 \mu$ g (fig. 8). A total of 22 of the 71 modules deployed at the MCTA detected BTEX above the MDL (fig. 9). Benzene is the main component of the BTEX detected in the samplers, but toluene and ethylbenzene also were detected in some samplers (table 2). Naphthalene was detected at sampler number 633448. Other compounds that were detected include octane at sampler numbers 633411 and 633456 and undecane and tridecane at sampler number 633412; 1,2,4-trimethylbenzene (TMB) at sampler numbers 633458 and 633459 ; chloroform at sampler numbers 633399 , $633414,633415,633419,633427,633428,633430$, and 6333436; TCE at sampler number 633439; PCE at sampler numbers 633428, 633439, and 633445; and, 1,4-dichlorobenzene at sampler number 633449 .

\section{Explosives and Chemical Agents}

The five soil-gas samplers deployed in the MCTA (fig. 5) had no detections of organic compounds classified as explosives or chemical agents above their respective MDLs, but some detections were above the nondetection level (table 3). Four compounds were detected below their MDL but above the nondetection level and were not detected in the trip blanks - dimethyl disulfide, benzothiazole, chloroacetophenones, and para-chlorophenyl methyl sulfide. The compound 2,4-dinitrotoluene was detected in a trip blank but not in the sample, and para-chlorophenyl methyl sulfone was detected in four of the five samples and in all five of the trip blanks; therefore, 2,4-dinitrotoluene and para-chlorphenyl methyl sulfone are not considered present in the sample.

\section{Soil Samples}

Composite soil samples were collected on August 30, 2010, at five locations in the MCTA (fig. 5). Metal concentrations in soil samples did not exceed the RSL for any of the five locations (tables 4-8). Some metal concentrations were, however, higher than background conditions reported for similar coastal plain sediments in South Carolina. Inorganic compound concentrations greater than background concentrations in South Carolina included aluminum, arsenic, barium, beryllium, chromium, copper, iron, lead, manganese, nickel, and potassium (tables 4-8).

\section{Surface-Water Sample}

A water sample was collected (in duplicate) from McCoys Creek east of the MCTA (fig. 5) and analyzed for 85 VOCs, 56 SVOCs (including PAHs), and 22 inorganics (metals; tables 9-11). No VOCs were detected in the surfacewater sample above the LRL; acetone and TCE were detected above the nondetection level, but below the LRL; therefore, the results were estimated (table 9). No VOCs or SVOCs were detected at levels above the MCL for the NPDWS (tables 9 and 10). Many inorganic compounds were detected, but only iron was detected at a concentration greater than the standard. Iron was detected at a concentration of $578 \mu \mathrm{g} / \mathrm{L}$ and exceeded the NSDWS MCL of $300 \mu \mathrm{g} / \mathrm{L}$ (table 11). No other inorganic compounds were detected above the MCL of the USEPA NPDWS, NSDWS, or the Georgia ISWQS. 


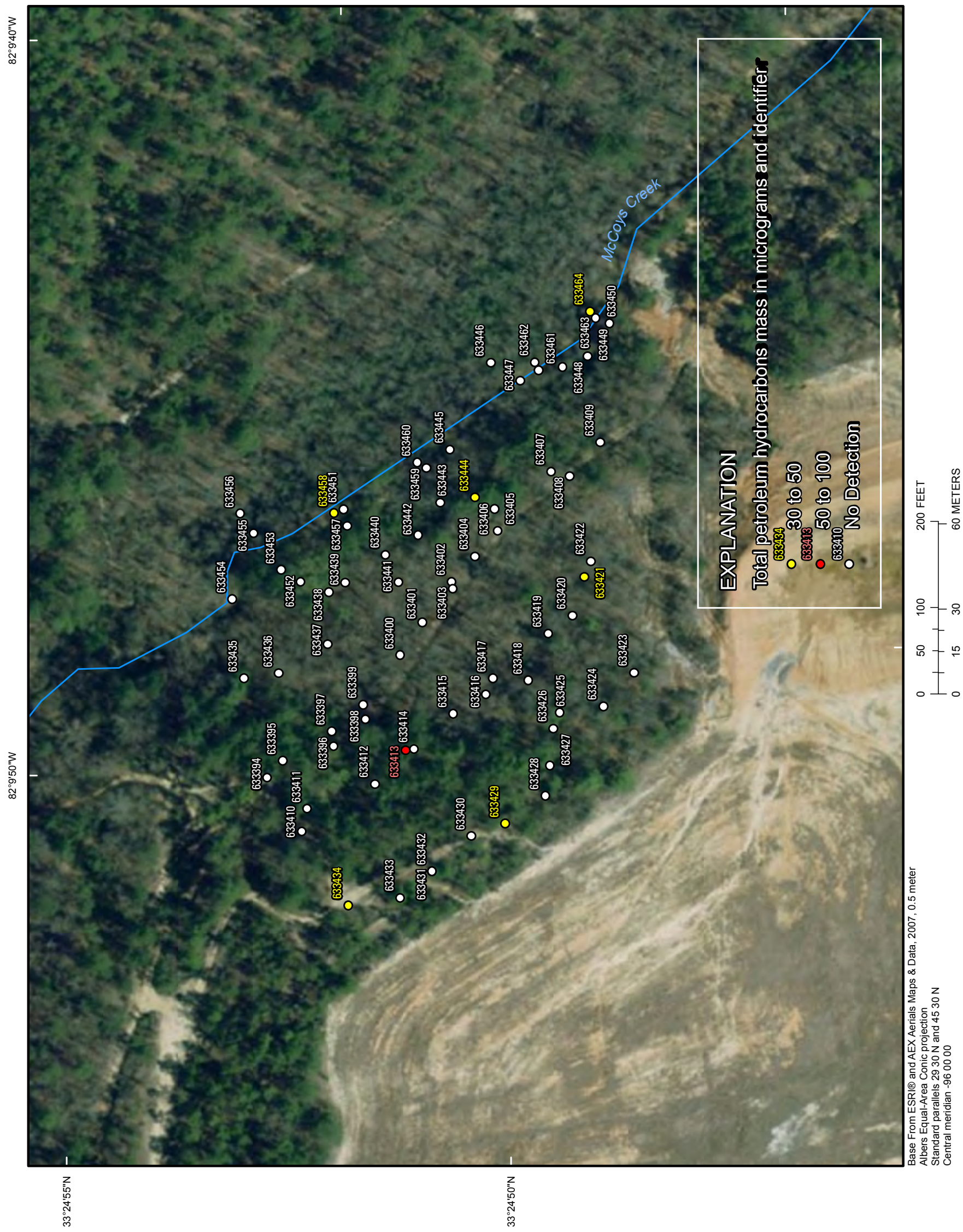

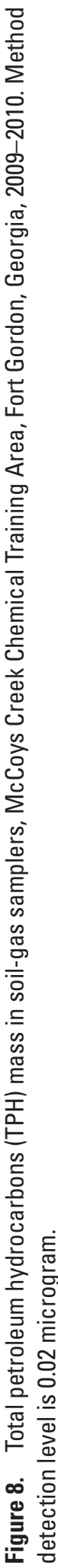




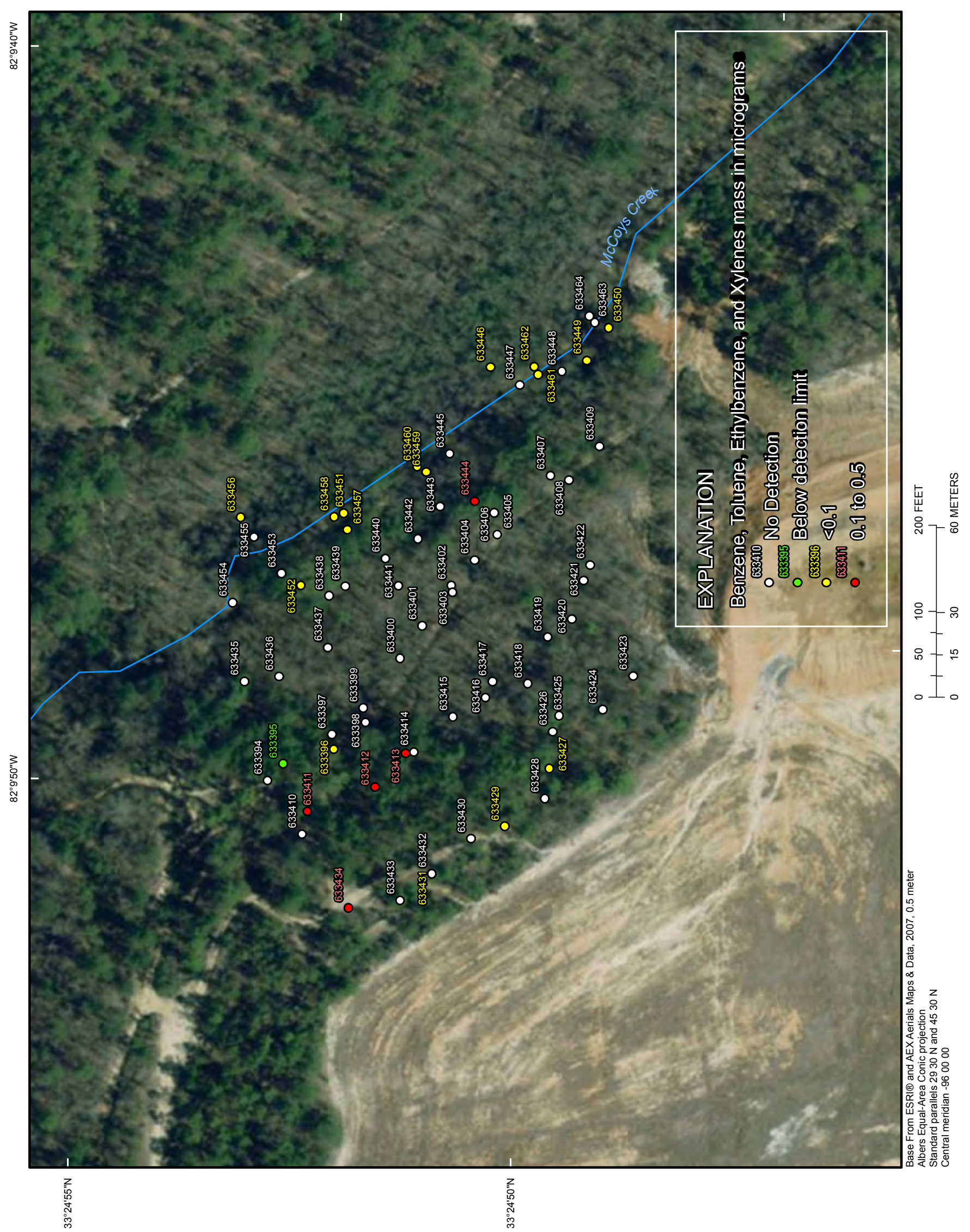

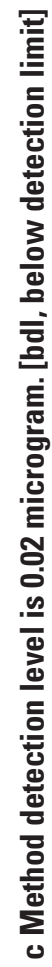




\section{Summary}

The U.S. Geological Survey, in cooperation with the Environmental and Natural Resources Management Office of the U.S. Army Signal Center and Fort Gordon, assessed the hyporheic zone, flood plain, soil gas, soil, and surface water for contaminants at the McCoys Creek Chemical Training Area (MCTA) at Fort Gordon, Georgia, from October 2009 to September 2010. The assessment included the detection of organic compounds in the hyporheic zone, flood plain, soil, and surface water. In addition, the organic contaminants assessment included the detection of organic compounds classified as explosives and chemical agents in selected locations. Also, surface-water and soil samples were analyzed for inorganic constituents. The assessment was conducted to provide environmental contamination data to the U.S. Army at Fort Gordon pursuant to requirements of the Resource Conservation and Resources Act Part B Hazardous Permit process.

The passive survey of the hyporheic zone and flood plain of McCoys Creek detected total petroleum hydrocarbons (TPH) and octane above their method detection levels in all 10 samplers that were deployed. Other compounds detected above their method detection levels in the hyporheic zone and flood-plain samplers included trichloroethylene, and cis- and trans-1,2-dichloroethylene. One trip blank detected TPH below the method detection level but above the nondetection level. The concentrations of TPH in the samplers were many times greater than the concentrations detected in the blank; therefore, TPH concentrations detected in the environmental samples are considered reliable.

Seventy-one soil-gas samplers were deployed in the MCTA. TPH was detected in all samplers, but trip blanks also detected TPH, and after censoring the data, only 7 of the 71 samplers detected TPH above the censored value. In addition, benzene, toluene, ethylbenzene, and total xylene (referred to BTEX) were detected in 22 of the 71 samplers. Also, sporadically detected in the soil-gas samplers were the polycyclic aromatic hydrocarbon naphthalene; the alkanes, octane, undecane and tridecane; and trichloroethylene, perchloroethylene, 1,2,4-trimethylbenzene, chloroform, and 1,4-dichlorobenzene, which were only detected at one or two locations each, respectively.

Five locations with elevated contaminant mass were selected in the MCTA to deploy soil-gas samplers to detect organic compounds classified as explosives and chemical agents, after the results of the soil-gas survey was evaluated. No explosives or chemical agents were detected in masses greater than the method detection level, but some were above the nondetection level. Dimethyl disulfide, benzothiazole, chloroacetophenones, and para-chlorophenyl methyl sulfide were all detected below the method detection level but above the nondetection level.

The same five locations that were selected for the installation of samplers to detect organic compounds classified as explosives and chemical agents were selected for the collection of soil samples. Metal concentrations in composite soil samples collected at five locations from land surface to a depth of 6 in below land surface did not exceed the U.S. Environmental Protection Agency Regional Screening Levels for Industrial Soil. Some compounds had concentrations higher than the South Carolina Department of Health and Environmental Control background concentrations, including aluminum, arsenic, barium, beryllium, chromium, copper, iron, lead, manganese, nickel, and potassium.

The surface-water sample collected from McCoys Creek was analyzed for 85 volatile organic compounds (VOC), 56 semivolatile organic compounds (SVOC), and 22 inorganic compounds (metals). No VOCs or SVOCs were detected above their laboratory reporting levels. Acetone and trichloroethene were detected at levels below the laboratory reporting level but above the nondetection level and, therefore, were estimated. The VOCs and SVOCs detected were at concentrations below the U.S. Environmental Protection Agency (USEPA) National Primary Drinking Water Standard maximum contaminant level for each compound. No inorganic compounds were detected above the maximum contaminant levels of the USEPA National Primary Drinking Water Standard, or the Georgia In-Stream Water Quality Standard. Iron (detected at $578 \mu \mathrm{g} / \mathrm{L}$ ) was the only inorganic compound detected in the surface-water sample that exceeded the USEPA National Secondary Drinking Water Standard maximum contaminant level for iron.

\section{References}

American Society for Testing and Materials, 2006, Standard guide for soil gas monitoring in the vadose zone: ASTM D5314-92, 36 p.

Briggs P.H., and Meier A.L., 2002, The determination of forty-two elements in geological materials by inductively coupled plasma-mass spectrometry, in Taggart J.E., Jr., ed. Analytical methods for chemical analysis of geologic and other materials: U.S. Geological Survey: Open-File Report 02-223, chapter I.

Childress, C.J.O., Foreman, W.T., Connor, B.F., and Maloney, T.J., 1999, New reporting procedures based on long-term method detection levels and some considerations for interpretations of water-quality data provided by the U.S. Geological Survey National Water Quality Laboratory: U.S. Geological Survey Open-File Report 99-193, 19 p.

Connor, B.F., Rose, D.L., Noriega, M.C., Murtagh, L., and Abney, S.R., 1997, Methods of analysis by the U.S. Geological Survey water quality laboratories - Determination of 86 volatile organic compounds in water by gas spectrometry, including detections less than reporting limits: U.S. Geological Survey Open-File Report 97-829, 78 p. 
Fishman, M.J, ed., 1993, Methods of analysis by the U.S. Geological Survey National Water Quality Laboratory-Determination of inorganic constituents in water and fluvial sediments: U.S. Geological Survey Open-File Report 93-125, 217 p.

Fishman, M.J., and Friedman, L.C., 1989, Methods for determination of inorganic substances in water and fluvial sediments: U.S. Geological Survey Techniques of WaterResources Investigations, book 5, chap. A1, 545 p.

Garbarino, J.R., and Damrau, D.L., 2001, Methods of analysis by the U.S. Geological Survey National Water Quality Laboratory-Determination of organic plus inorganic in filtered and unfiltered natural waters with cold vapor-Atomic fluorescence spectrometry: U.S. Geological Survey WaterResources Investigations Report 01-4132, 16 p.

Garbarino, J.R., Kanagt, L.K., and Cree, M.E., 2006, Determination of elements in natural water, biota, sediment, and soil samples using collision/reaction cell inductively coupled plasma-mass spectrometry: U.S. Geological Survey Techniques and Methods, book 5, sec. B, chap. 1, 88 p.

Garbarino, J.R., and Struzeski, T.M., 1998, Methods of analysis by the U.S. Geological Survey National Water Quality Laboratory-Determination of elements in wholewater digests using inductively coupled plasma-optical emissions spectrometry and inductively coupled plasmamass spectrometry: U.S. Geological Survey Open-File Report 98-165, $101 \mathrm{p}$.

Georgia Environmental Protection Division, 2005, Rules and regulations for water quality control: Georgia Department of Natural Resources, chapter 391-3-6, revised November 2005, 141 p., accessed July 8, 2011, at http://water.epa.gov/scitech/swguidance/standards/ upload/2006_02_01_standards_wqslibrary_ga_ga_4_wqs. pdf.

Gregory, M.B., Stamey, T.C., and Wellborn, J.B., 2001, Ecological characterization of streams, and fish-tissue analysis for mercury and lead at selected locations, Fort Gordon, Georgia, June 1999 to May 2000: U.S. Geological Survey Open-File Report 01-203, 14 p.

Hoffman, G.L., Fishman, M.J., and Garbarino, J.R., 1996, Methods of analysis by the U.S. Geological Survey National Water Quality Laboratory-In-bottle acid digestion of whole-water samples: U.S. Geological Survey Open-File Report 96-225, 28 p.
International Organization for Standardization, 1990, ISO guide 25-General requirements for the competence of calibration and testing laboratories ( $3 \mathrm{~d}$ ed.): New York, American National Standards Institute.

South Carolina Department of Health and Environmental Control, 2002, Environmental Surveillance and Oversight Program data report, 2002: Accessed February 11, 2010, at http://www.scdhec.gov/environment/envserv/docs/ esop_datarpt_02.pdf.

U.S. Environmental Protection Agency, 1998, Innovative technology verification report soil gas sampling technology: EPA/600/R-98/095.

U.S. Environmental Protection Agency, 2009a, Regional screening level tables: Accessed January 12, 2010, at http://www.epa.gov/reg3hwmd/risk/human/ rb-concentration_table/Generic_Tables/index.htm.

U.S. Environmental Protection Agency, 2009b, Edition of the drinking water standards and health advisories: Washington, D.C., EPA 822-R-09-011, accessed January 11, 2011, at http://www.epa.gov/waterscience/criteria/ drinking/dwstandards.pdf.

U.S. Geological Survey, variously dated, National field manual for the collection of water-quality data: U.S. Geological Survey Techniques of Water-Resources Investigations, book 9, chap. A1, January, accessed January 19, 2010 , at http://pubs.water.usgs.gov/ywri9A2/.

U.S Geological Survey, 1997, NWIS-New remark code (V) for water-quality data: U.S. Geological Survey Office of Water Quality Technical Memorandum 97.08, 2 p., accessed May 24, 2011, at http://water.usgs.gov/admin/memo/QW/ qw97.08.html.

Williams, L.J., 2007, Hydrogeology and potentiometric surface of the Dublin and Midville aquifer systems in Richmond County, Georgia, January 2007: U.S. Geological Survey Scientific Investigations Map 2982, 1 sheet.

W.L. Gore and Associates, Inc., 2004, Surveys for environmental site assessment: Accessed March 19, 2010, at http://www.gore.com/MungoBlobs/239/659/surveys_ environmental_brochure.pdf. 
Table 1. Concentrations of organic compounds detected in the hyphoreic zone and flood-plain samplers collected from McCoys Creek, McCoys Creek Chemical Training Area, Fort Gordon, Georgia, 2009-2010.

[TPH, total petroleum hydrocarbon; $\mu \mathrm{g} / \mathrm{L}$, microgram per liter; BTEX, summation of benzene, toluene, ethylbenzene, and total xylene; $m$, $m e t a ; ~ p, p a r a$;

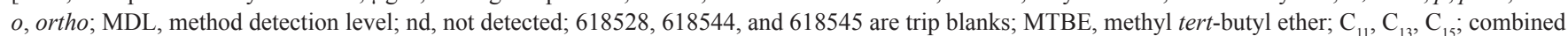
concentrations of undecane, tridecane, and pentadecane; DCA, dichlorethane; TCA, trichloroethane; TCE, trichloroethylene; PCE, perchloroethylene; $c$, cis; $t$, trans; DCE, dichloroethylene; $\mathrm{CCl}_{4}$, carbon tetrachloride; $\mathrm{DCB}$, dichlorobenzene]

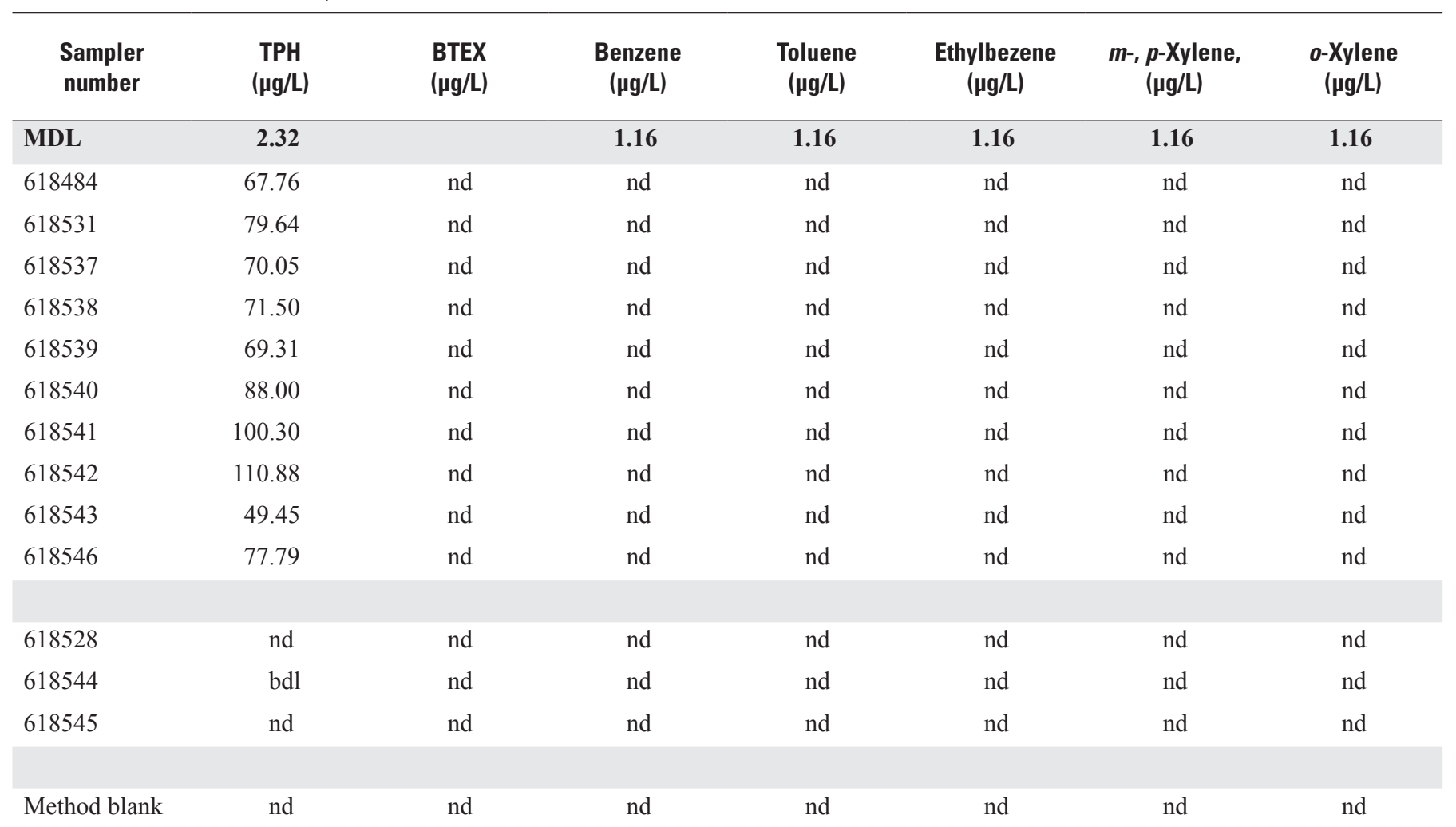


Table 1. Concentrations of organic compounds detected in the hyphoreic zone and flood-plain samplers collected from McCoys Creek, McCoys Creek Chemical Training Area, Fort Gordon, Georgia, 2009-2010.-Continued

[TPH, total petroleum hydrocarbon; $\mu \mathrm{g} / \mathrm{L}$, microgram per liter; BTEX, summation of benzene, toluene, ethylbenzene, and total xylene; $m$, meta; , para; o, ortho; MDL, method detection level; nd, not detected; 618528, 618544, and 618545 are trip blanks; MTBE, methyl tert-butyl ether; $\mathrm{C}_{11}, \mathrm{C}_{13}, \mathrm{C}_{15}$; combined concentrations of undecane, tridecane, and pentadecane; DCA, dichlorethane; TCA, trichloroethane; TCE, trichloroethylene; PCE, perchloroethylene; $c$, cis; $t$, trans; DCE, dichloroethylene; $\mathrm{CCl}_{4}$, carbon tetrachloride; DCB, dichlorobenzene]

\begin{tabular}{lcccc}
\hline $\begin{array}{c}\text { Sampler } \\
\text { number }\end{array}$ & $\begin{array}{c}\text { Naphthalene, } \\
(\boldsymbol{\mu} \mathbf{g} / \mathbf{L})\end{array}$ & $\begin{array}{c}\text { 2-Methyl- } \\
\text { naphthalene } \\
(\boldsymbol{\mu} \mathbf{g} / \mathbf{L})\end{array}$ & $\begin{array}{c}\text { MTBE } \\
(\boldsymbol{\mu} \mathbf{g} / \mathbf{L})\end{array}$ & $\begin{array}{c}\text { Octane } \\
(\boldsymbol{\mu} \mathbf{g} / \mathbf{L})\end{array}$ \\
\hline MDL & $\mathbf{1 . 1 6}$ & $\mathbf{1 . 1 6}$ & $\mathbf{2 . 3 2}$ & $\mathbf{1 . 1 6}$ \\
618484 & nd & nd & nd & 2.20 \\
618531 & nd & nd & nd & 2.63 \\
618537 & nd & nd & nd & 2.23 \\
618538 & nd & nd & nd & 2.32 \\
618539 & nd & nd & nd & 2.24 \\
618540 & nd & nd & nd & 3.00 \\
618541 & nd & nd & nd & 3.09 \\
618542 & nd & nd & nd & 3.42 \\
618543 & nd & nd & nd & 1.75 \\
618546 & nd & nd & nd & 2.53 \\
618528 & & & & \\
618544 & nd & nd & nd & nd \\
618545 & nd & nd & nd & nd \\
\hline Method blank & nd & nd & nd \\
\hline
\end{tabular}


Table 1. Concentrations of organic compounds detected in the hyphoreic zone and flood-plain samplers collected from McCoys Creek, McCoys Creek Chemical Training Area, Fort Gordon, Georgia, 2009-2010.-Continued

[TPH, total petroleum hydrocarbon; $\mu \mathrm{g} / \mathrm{L}$, microgram per liter; BTEX, summation of benzene, toluene, ethylbenzene, and total xylene; $m$, meta; , para; $o$, ortho; MDL, method detection level; nd, not detected; 618528, 618544, and 618545 are trip blanks; MTBE, methyl tert-butyl ether; $\mathrm{C}_{11}, \mathrm{C}_{13}, \mathrm{C}_{15}$; combined concentrations of undecane, tridecane, and pentadecane; DCA, dichlorethane; TCA, trichloroethane; TCE, trichloroethylene; PCE, perchloroethylene; $c$, cis; $t$, trans; DCE, dichloroethylene; $\mathrm{CCl}_{4}$, carbon tetrachloride; $\mathrm{DCB}$, dichlorobenzene]

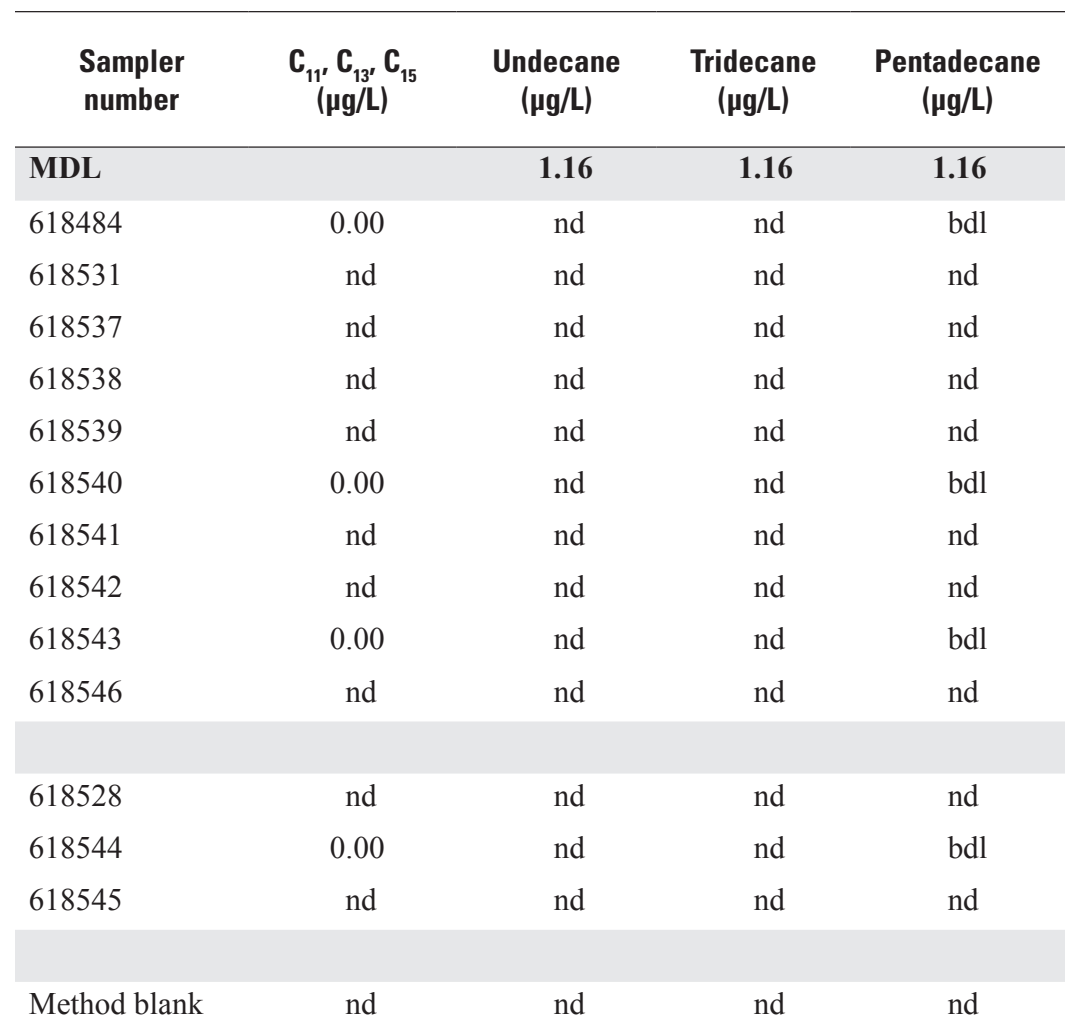


Table 1. Concentrations of organic compounds detected in the hyphoreic zone and flood-plain samplers collected from McCoys Creek, McCoys Creek Chemical Training Area, Fort Gordon, Georgia, 2009-2010._Continued

[TPH, total petroleum hydrocarbon; $\mu \mathrm{g} / \mathrm{L}$, microgram per liter; BTEX, summation of benzene, toluene, ethylbenzene, and total xylene; $m$, $m e t a ; ~ p, p a r a$;

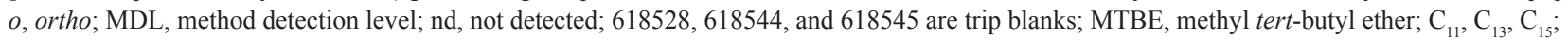
combined concentrations of undecane, tridecane, and pentadecane; DCA, dichlorethane; TCA, trichloroethane; TCE, trichloroethylene; PCE, perchloroethylene; $c$, cis; $t$, trans; DCE, dichloroethylene; $\mathrm{CCl}_{4}$, carbon tetrachloride; DCB, dichlorobenzene]

\begin{tabular}{|c|c|c|c|c|c|c|c|}
\hline $\begin{array}{l}\text { Sampler } \\
\text { number }\end{array}$ & $\begin{array}{c}\text { Trimethyl } \\
\text { benzenes } \\
(\mu \mathrm{g} / \mathrm{L})\end{array}$ & $\begin{array}{l}\text { 1,2,4,-Trimethyl } \\
\text { benzene } \\
(\mu \mathrm{g} / \mathrm{L})\end{array}$ & $\begin{array}{l}\text { 1,3,5-Trimethyl } \\
\text { benzene } \\
(\mu \mathrm{g} / \mathrm{L})\end{array}$ & $\begin{array}{c}\text { 1,1-DCA } \\
(\mu \mathrm{g} / \mathrm{L})\end{array}$ & $\begin{array}{l}\text { Chloroform } \\
\qquad(\mu \mathrm{g} / \mathrm{L})\end{array}$ & $\begin{array}{c}1,1,1-\mathrm{TCA} \\
(\mu \mathrm{g} / \mathrm{L})\end{array}$ & $\begin{array}{c}c-1,2-D C A \\
(\mu \mathrm{g} / \mathrm{L})\end{array}$ \\
\hline MDL & & 1.16 & 1.16 & 1.16 & 1.16 & 1.16 & 1.16 \\
\hline 618484 & nd & nd & nd & nd & nd & nd & nd \\
\hline 618531 & nd & nd & nd & nd & nd & nd & nd \\
\hline 618537 & nd & nd & nd & nd & nd & nd & nd \\
\hline 618538 & nd & nd & nd & nd & nd & nd & nd \\
\hline 618539 & nd & nd & nd & nd & nd & nd & nd \\
\hline 618540 & nd & nd & nd & nd & nd & nd & nd \\
\hline 618540 & nd & nd & nd & nd & nd & nd & nd \\
\hline 618541 & nd & nd & nd & nd & nd & nd & nd \\
\hline 618542 & nd & nd & nd & nd & nd & nd & nd \\
\hline 618543 & nd & nd & nd & nd & nd & nd & nd \\
\hline 618546 & nd & nd & nd & nd & nd & nd & nd \\
\hline 618528 & nd & nd & nd & nd & nd & nd & nd \\
\hline 618544 & nd & nd & nd & nd & nd & nd & nd \\
\hline 618545 & nd & nd & nd & nd & nd & nd & nd \\
\hline Method blank & nd & nd & nd & nd & nd & nd & nd \\
\hline
\end{tabular}


Table 1. Concentrations of organic compounds detected in the hyphoreic zone and flood-plain samplers collected from McCoys Creek, McCoys Creek Chemical Training Area, Fort Gordon, Georgia, 2009-2010.—Continued

[TPH, total petroleum hydrocarbon; $\mu \mathrm{g} / \mathrm{L}$, microgram per liter; BTEX, summation of benzene, toluene, ethylbenzene, and total xylene; m, meta; $p$, para; $o$, ortho; MDL, method detection level; nd, not detected; 618528, 618544, and 618545 are trip blanks; MTBE, methyl tert-butyl ether; $\mathrm{C}_{11}, \mathrm{C}_{13}, \mathrm{C}_{15}$; combined concentrations of undecane, tridecane, and pentadecane; DCA, dichlorethane; TCA, trichloroethane; TCE, trichloroethylene; PCE, perchloroethylene; $c$, cis; $t$, trans; DCE, dichloroethylene; $\mathrm{CCl}_{4}$, carbon tetrachloride; $\mathrm{DCB}$, dichlorobenzene]

\begin{tabular}{|c|c|c|c|c|c|}
\hline $\begin{array}{l}\text { Sampler } \\
\text { number }\end{array}$ & $\begin{array}{c}\text { TCE } \\
(\mu \mathrm{g} / \mathrm{L})\end{array}$ & $\begin{array}{l}\text { PCE } \\
(\mu \mathrm{g} / \mathrm{L})\end{array}$ & $\begin{array}{c}c, t-1,2-D C E \\
(\mu \mathrm{g} / \mathrm{L})\end{array}$ & $\begin{array}{c}t-1,2-D C E \\
(\mu \mathrm{g} / \mathrm{L})\end{array}$ & $\begin{array}{c}c-1,2-D C E \\
(\mu \mathrm{g} / \mathrm{L})\end{array}$ \\
\hline MDL & 1.16 & 1.16 & & 4.01 & 1.20 \\
\hline 618484 & nd & nd & nd & nd & nd \\
\hline 618531 & 40.20 & nd & 49.68 & 5.96 & 43.73 \\
\hline 618537 & nd & nd & nd & nd & nd \\
\hline 618538 & nd & nd & nd & nd & nd \\
\hline 618539 & 1.70 & nd & nd & nd & nd \\
\hline 618540 & nd & nd & nd & nd & nd \\
\hline 618541 & nd & nd & nd & nd & nd \\
\hline 618542 & nd & nd & nd & nd & nd \\
\hline 618543 & nd & nd & nd & nd & nd \\
\hline 618546 & nd & nd & nd & nd & nd \\
\hline 618528 & nd & nd & nd & nd & nd \\
\hline 618544 & nd & nd & nd & nd & nd \\
\hline 618545 & nd & nd & nd & nd & nd \\
\hline Method blank & nd & nd & nd & nd & nd \\
\hline
\end{tabular}


Table 1. Concentrations of organic compounds detected in the hyphoreic zone and flood-plain samplers collected from McCoys Creek, McCoys Creek Chemical Training Area, Fort Gordon, Georgia, 2009-2010._Continued

[TPH, total petroleum hydrocarbon; $\mu \mathrm{g} / \mathrm{L}$, microgram per liter; BTEX, summation of benzene, toluene, ethylbenzene, and total xylene; $m$, meta; p, para; o, ortho; MDL, method detection level; nd, not detected; 618528, 618544, and 618545 are trip blanks; MTBE, methyl tertbutyl ether; $\mathrm{C}_{11}, \mathrm{C}_{13}, \mathrm{C}_{15}$; combined concentrations of undecane, tridecane, and pentadecane; DCA, dichlorethane; TCA, trichloroethane; TCE, trichloroethylene; PCE, perchloroethylene; $c$, cis; $t$, trans; DCE, dichloroethylene; $\mathrm{CCl}_{4}$, carbon tetrachloride; DCB, dichlorobenzene]

\begin{tabular}{|c|c|c|c|c|c|c|}
\hline $\begin{array}{l}\text { Sampler } \\
\text { number }\end{array}$ & $\begin{array}{c}\mathrm{CCI}_{4} \\
(\mu \mathrm{g} / \mathrm{L})\end{array}$ & $\begin{array}{c}\text { 1,4-DCB } \\
(\mu \mathrm{g} / \mathrm{L})\end{array}$ & $\begin{array}{c}\text { 1,1,2-TCA } \\
(\mu \mathrm{g} / \mathrm{L})\end{array}$ & $\begin{array}{c}\text { Chlorobenzene } \\
\text { ( } \mu \mathrm{g} / \mathrm{L})\end{array}$ & $\begin{array}{c}\text { 1,1,1,2-Tetra- } \\
\text { chloroethane } \\
(\mu \mathrm{g} / \mathrm{L})\end{array}$ & $\begin{array}{c}\text { 1,1,2,2-Tetra- } \\
\text { chloroethane } \\
(\mu \mathrm{g} / \mathrm{L})\end{array}$ \\
\hline MDL & 1.16 & 1.16 & 1.16 & 1.16 & 1.16 & 1.16 \\
\hline 618484 & nd & nd & nd & nd & nd & nd \\
\hline 618531 & nd & nd & nd & nd & nd & nd \\
\hline 618537 & nd & nd & nd & nd & nd & nd \\
\hline 618538 & nd & nd & nd & nd & nd & nd \\
\hline 618539 & nd & nd & nd & nd & nd & nd \\
\hline 618540 & nd & nd & nd & nd & nd & nd \\
\hline 618541 & nd & nd & nd & nd & nd & nd \\
\hline 618542 & nd & nd & nd & nd & nd & nd \\
\hline 618543 & nd & nd & nd & nd & nd & nd \\
\hline 618546 & nd & nd & nd & nd & nd & nd \\
\hline 618528 & nd & nd & nd & nd & nd & nd \\
\hline 618544 & nd & nd & nd & nd & nd & nd \\
\hline 618545 & nd & nd & nd & nd & nd & nd \\
\hline
\end{tabular}


Table 1. Concentrations of organic compounds detected in the hyphoreic zone and flood-plain samplers collected from McCoys Creek, McCoys Creek Chemical Training Area, Fort Gordon, Georgia, 2009-2010.-Continued

$[\mathrm{TPH}$, total petroleum hydrocarbon; $\mu \mathrm{g} / \mathrm{L}$, microgram per liter; BTEX, summation of benzene, toluene, ethylbenzene, and total xylene; $m$, meta; p, para; o, ortho; MDL, method detection level; nd, not detected; 618528, 618544 , and 618545 are trip blanks; MTBE, methyl tert-butyl ether; $\mathrm{C}_{11}$, $\mathrm{C}_{13}, \mathrm{C}_{15}$; combined concentrations of undecane, tridecane, and pentadecane; DCA, dichlorethane; TCA, trichloroethane; TCE, trichloroethylene; PCE, perchloroethylene; $c$, cis; $t$, trans; DCE, dichloroethylene; $\mathrm{CCl}_{4}$, carbon tetrachloride; DCB, dichlorobenzene]

\begin{tabular}{|c|c|c|}
\hline $\begin{array}{l}\text { Sampler } \\
\text { number }\end{array}$ & $\begin{array}{c}\text { 1,3-Dichlorobenzene } \\
(\mu \mathrm{g} / \mathrm{L})\end{array}$ & $\begin{array}{c}\text { 1,2-Dichlorobenzent } \\
(\mu \mathrm{g} / \mathrm{L})\end{array}$ \\
\hline MDL & 1.16 & 1.16 \\
\hline 618484 & nd & nd \\
\hline 618531 & nd & nd \\
\hline 618537 & nd & nd \\
\hline 618538 & nd & nd \\
\hline 618539 & nd & nd \\
\hline 618540 & nd & nd \\
\hline 618541 & nd & nd \\
\hline 618542 & nd & nd \\
\hline 618543 & nd & nd \\
\hline 618546 & nd & nd \\
\hline 618528 & nd & nd \\
\hline 618544 & nd & nd \\
\hline 618545 & nd & nd \\
\hline Method blank & nd & nd \\
\hline
\end{tabular}


Table 2. Mass of organic compounds detected in soil-gas samplers, McCoys Creek Chemical Training Area, Fort Gordon, Georgia, 2009-2010.

$[\mathrm{TPH}$, total petroleum hydrocarbon; $\mu \mathrm{g}$, microgram; BTEX, combined masses of benzene, toluene, ethylbenzene and total xylenes; $m-$, meta; $p$-, para; $o$-, ortho; MDL, method detection level; nd, not detected; 633465, 633466 and 633467 are trip blanks; MTBE, methyl tert-butyl ether; $\mathrm{C}_{11}, \mathrm{C}_{13}, \mathrm{C}_{15}$; combined masses of undecane, tridecane, and pentadecane; DCA, dichlorethane; TCA, trichloroethane; TCE, trichloroethylene, DCE, dichloroethylene; PCE, perchloroethylene; DCB, dichlorobenzene; $\mathrm{CCl}_{4}$, carbon tetrachloride]

\begin{tabular}{|c|c|c|c|c|c|c|c|}
\hline $\begin{array}{c}\text { Sampler } \\
\text { number }\end{array}$ & $\begin{array}{l}\text { TPH } \\
(\mu \mathrm{g})\end{array}$ & $\begin{array}{l}\text { BTEX } \\
(\mu \mathrm{g})\end{array}$ & $\begin{array}{c}\text { Benzene } \\
(\mu \mathrm{g})\end{array}$ & $\begin{array}{c}\text { Toluene } \\
(\mu \mathrm{g})\end{array}$ & $\begin{array}{c}\text { Ethylbenzene } \\
(\mu \mathrm{g})\end{array}$ & $\begin{array}{c}m-, p \text {-Xylene } \\
(\mu \mathrm{g})\end{array}$ & $\begin{array}{c}\text { o-Xylene } \\
(\mu \mathrm{g})\end{array}$ \\
\hline MDL & 0.02 & & 0.02 & 0.02 & 0.02 & 0.03 & 0.02 \\
\hline 633394 & 1.35 & nd & nd & nd & nd & nd & nd \\
\hline 633395 & 12.35 & 0.00 & nd & bdl & nd & nd & nd \\
\hline 633396 & 2.36 & 0.07 & 0.03 & 0.05 & nd & nd & nd \\
\hline 633397 & 0.37 & nd & nd & nd & nd & nd & nd \\
\hline 633398 & 1.12 & nd & nd & nd & nd & nd & nd \\
\hline 633399 & 0.68 & nd & nd & nd & nd & nd & nd \\
\hline 633400 & 0.30 & nd & nd & nd & nd & nd & nd \\
\hline 633401 & 7.37 & nd & nd & nd & nd & nd & nd \\
\hline 633402 & 0.50 & nd & nd & nd & nd & nd & nd \\
\hline 633403 & 10.49 & nd & nd & nd & nd & nd & nd \\
\hline 633404 & 3.35 & nd & nd & nd & nd & nd & nd \\
\hline 633405 & 12.48 & nd & nd & nd & nd & nd & nd \\
\hline 633406 & 0.53 & nd & nd & nd & nd & nd & nd \\
\hline 633407 & 5.87 & nd & nd & nd & nd & nd & nd \\
\hline 633408 & 0.93 & nd & nd & nd & nd & nd & nd \\
\hline 633409 & 0.33 & nd & nd & nd & nd & nd & nd \\
\hline 633410 & 1.38 & nd & nd & nd & nd & nd & nd \\
\hline 633411 & 6.00 & 0.38 & 0.08 & 0.28 & 0.02 & bdl & bdl \\
\hline 633412 & 15.16 & 0.16 & 0.04 & 0.11 & $\mathrm{nd}$ & nd & nd \\
\hline 633413 & 90.75 & 0.15 & nd & 0.15 & nd & nd & nd \\
\hline 633414 & 2.92 & nd & nd & nd & nd & nd & nd \\
\hline 633415 & 2.85 & nd & nd & nd & nd & nd & nd \\
\hline 633416 & 4.12 & nd & nd & nd & nd & nd & nd \\
\hline 633417 & 1.39 & nd & nd & nd & nd & nd & nd \\
\hline 633418 & 1.14 & nd & nd & nd & nd & nd & nd \\
\hline 633419 & 4.04 & nd & nd & nd & nd & nd & nd \\
\hline 633420 & 2.18 & nd & nd & nd & nd & nd & nd \\
\hline 633421 & 34.14 & nd & nd & nd & nd & nd & nd \\
\hline 633422 & 1.58 & nd & nd & nd & nd & nd & nd \\
\hline 633423 & 1.22 & nd & nd & nd & nd & nd & nd \\
\hline 633424 & 1.23 & nd & nd & nd & nd & nd & nd \\
\hline 633425 & 0.61 & nd & nd & nd & nd & nd & nd \\
\hline 633426 & 0.37 & nd & nd & nd & nd & nd & nd \\
\hline 633427 & 26.11 & 0.03 & nd & 0.03 & nd & nd & nd \\
\hline 633428 & 14.51 & nd & nd & nd & nd & nd & nd \\
\hline 633429 & 44.11 & 0.05 & nd & 0.05 & nd & nd & nd \\
\hline 633430 & 2.10 & nd & nd & nd & nd & nd & nd \\
\hline 633431 & 16.44 & 0.02 & nd & 0.02 & nd & nd & nd \\
\hline 633432 & 4.24 & nd & nd & nd & nd & nd & nd \\
\hline 633433 & 8.21 & nd & nd & nd & nd & nd & nd \\
\hline 633434 & 32.39 & 0.15 & nd & 0.15 & nd & nd & nd \\
\hline 633435 & 0.43 & nd & nd & nd & nd & nd & nd \\
\hline 633436 & 2.33 & nd & nd & nd & nd & nd & nd \\
\hline
\end{tabular}


Table 2. Mass of organic compounds detected in soil-gas samplers, McCoys Creek Chemical Training Area, Fort Gordon, Georgia, 2009-2010.-Continued

[TPH, total petroleum hydrocarbon; $\mu \mathrm{g}$, microgram; BTEX, combined masses of benzene, toluene, ethylbenzene and total xylenes; $m$-, meta; $p$-, para; $o$-, ortho; MDL, method detection level; nd, not detected; 633465, 633466 and 633467 are trip blanks; MTBE, methyl tert-butyl ether; $\mathrm{C}_{11}, \mathrm{C}_{13}, \mathrm{C}_{15} ;$ combined masses of undecane, tridecane, and pentadecane; DCA, dichlorethane; TCA, trichloroethane; TCE, trichloroethylene, DCE, dichloroethylene; PCE, perchloroethylene; $\mathrm{DCB}$, dichlorobenzene; $\mathrm{CCl}_{4}$, carbon tetrachloride]

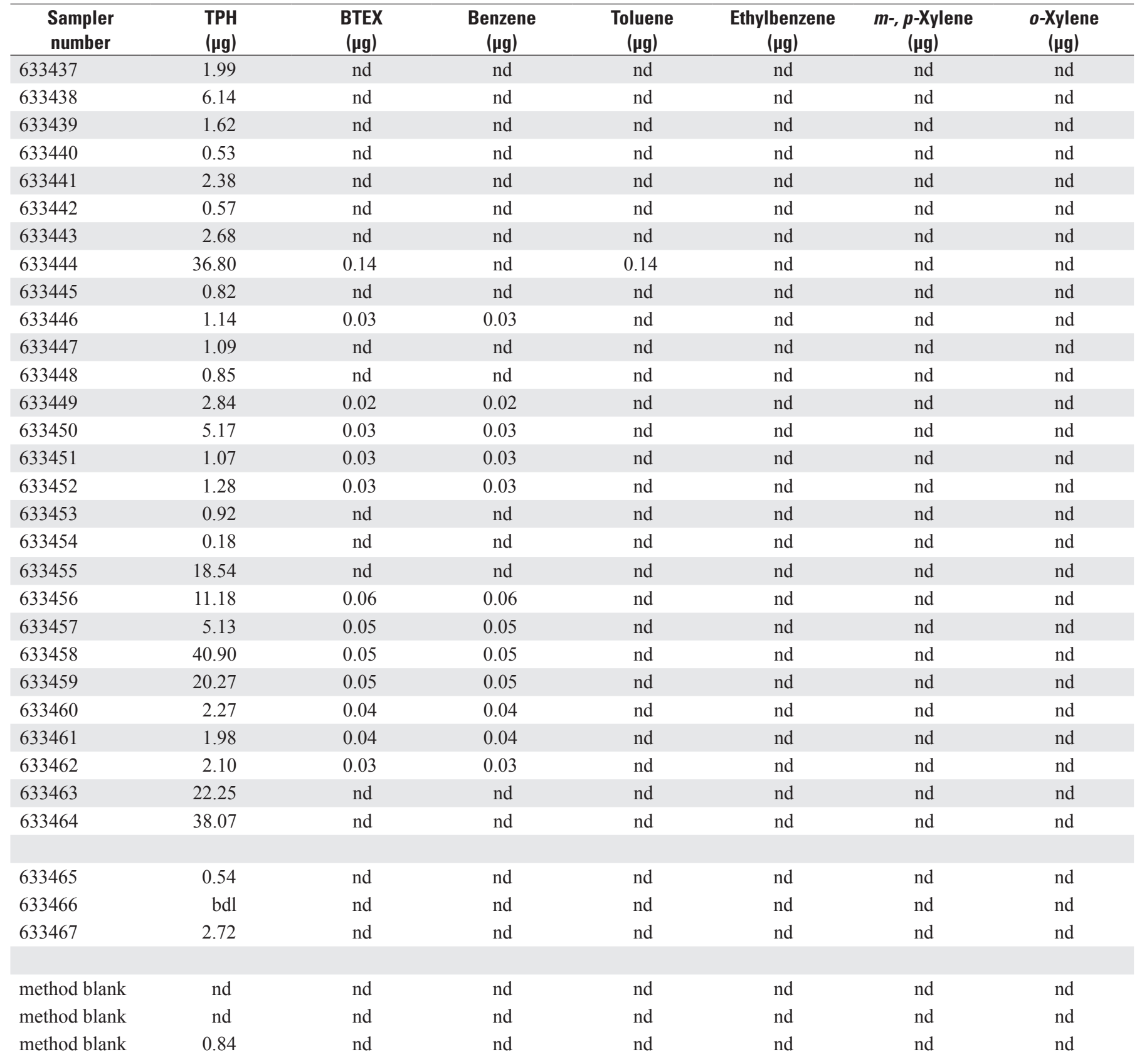


Table 2. Mass of organic compounds detected in soil-gas samplers, McCoys Creek Chemical Training Area, Fort Gordon, Georgia, 2009-2010.-Continued

[TPH, total petroleum hydrocarbon; $\mu \mathrm{g}$, microgram; BTEX, combined masses of benzene, toluene, ethylbenzene and total xylenes; $m$-, meta; $p$-, para; o-, ortho; MDL, method detection level; nd, not detected; 633465, 633466 and 633467 are trip blanks; MTBE, methyl tert-butyl ether; $\mathrm{C}_{11}, \mathrm{C}_{13}, \mathrm{C}_{15}$; combined masses of undecane, tridecane, and pentadecane; DCA, dichlorethane; TCA, trichloroethane; TCE, trichloroethylene, DCE, dichloroethylene; PCE, perchloroethylene; $\mathrm{DCB}$, dichlorobenzene; $\mathrm{CCl}_{4}$, carbon tetrachloride]

\begin{tabular}{|c|c|c|c|c|}
\hline $\begin{array}{l}\text { Sampler } \\
\text { number }\end{array}$ & $\begin{array}{c}\text { Naphthalene } \\
(\mu g)\end{array}$ & $\begin{array}{c}\text { 2-Methyl- } \\
\text { naphthalene } \\
(\mu \mathrm{g})\end{array}$ & $\begin{array}{c}\text { MTBE } \\
(\mu \mathrm{g})\end{array}$ & $\begin{array}{c}\text { Octane } \\
(\mu \mathrm{g})\end{array}$ \\
\hline MDL & 0.02 & 0.02 & 0.03 & 0.02 \\
\hline 633394 & nd & nd & nd & nd \\
\hline 633395 & nd & nd & nd & nd \\
\hline 633396 & nd & nd & nd & nd \\
\hline 633397 & nd & nd & nd & nd \\
\hline 633398 & nd & nd & nd & nd \\
\hline 633399 & nd & nd & nd & nd \\
\hline 633400 & nd & nd & nd & nd \\
\hline 633401 & nd & nd & nd & nd \\
\hline 633402 & nd & nd & nd & nd \\
\hline 633403 & nd & nd & nd & nd \\
\hline 633404 & nd & nd & nd & nd \\
\hline 633405 & nd & nd & nd & nd \\
\hline 633406 & nd & nd & nd & nd \\
\hline 633407 & nd & nd & nd & nd \\
\hline 633408 & nd & nd & nd & nd \\
\hline 633409 & nd & nd & nd & nd \\
\hline 633410 & nd & nd & nd & nd \\
\hline 633411 & nd & nd & nd & 0.05 \\
\hline 633412 & nd & nd & nd & nd \\
\hline 633413 & nd & nd & nd & nd \\
\hline 633414 & nd & nd & nd & nd \\
\hline 633415 & nd & nd & nd & nd \\
\hline 633416 & nd & nd & nd & nd \\
\hline 633417 & nd & nd & nd & nd \\
\hline 633418 & nd & nd & nd & nd \\
\hline 633419 & nd & nd & nd & nd \\
\hline 633420 & nd & nd & nd & nd \\
\hline 633421 & nd & nd & nd & nd \\
\hline 633422 & nd & nd & nd & nd \\
\hline 633423 & nd & nd & nd & nd \\
\hline 633424 & nd & nd & nd & nd \\
\hline 633425 & nd & nd & nd & nd \\
\hline 633426 & nd & nd & nd & nd \\
\hline 633427 & nd & nd & nd & nd \\
\hline 633428 & nd & nd & nd & nd \\
\hline 633429 & nd & nd & nd & nd \\
\hline 633430 & nd & nd & nd & nd \\
\hline 633431 & nd & nd & nd & nd \\
\hline 633432 & nd & nd & nd & nd \\
\hline 633433 & nd & nd & nd & nd \\
\hline 633434 & nd & nd & nd & nd \\
\hline 633435 & nd & nd & nd & nd \\
\hline
\end{tabular}


Table 2. Mass of organic compounds detected in soil-gas samplers, McCoys Creek Chemical Training Area, Fort Gordon, Georgia, 2009-2010.-Continued

$[\mathrm{TPH}$, total petroleum hydrocarbon; $\mu \mathrm{g}$, microgram; BTEX, combined masses of benzene, toluene, ethylbenzene and total xylenes; $m$-, meta; $p$-, para; o-, ortho; MDL, method detection level; nd, not detected; 633465 , 633466 and 633467 are trip blanks; MTBE, methyl tert-butyl ether; $\mathrm{C}_{11}, \mathrm{C}_{13}, \mathrm{C}_{15}$; combined masses of undecane, tridecane, and pentadecane; DCA, dichlorethane; TCA, trichloroethane; TCE, trichloroethylene, DCE, dichloroethylene; PCE, perchloroethylene; $\mathrm{DCB}$, dichlorobenzene; $\mathrm{CCl}_{4}$, carbon tetrachloride]

\begin{tabular}{|c|c|c|c|c|}
\hline $\begin{array}{l}\text { Sampler } \\
\text { number }\end{array}$ & $\begin{array}{c}\text { Naphthalene } \\
(\mu \mathrm{g})\end{array}$ & $\begin{array}{c}\text { 2-Methyl- } \\
\text { naphthalene } \\
\text { ( } \mu \mathrm{g})\end{array}$ & $\begin{array}{c}\text { MTBE } \\
(\mu g)\end{array}$ & $\begin{array}{c}\text { Octane } \\
(\mu \mathrm{g})\end{array}$ \\
\hline 633436 & nd & nd & nd & nd \\
\hline 633437 & nd & nd & nd & nd \\
\hline 633438 & nd & nd & nd & nd \\
\hline 633439 & nd & nd & nd & nd \\
\hline 633440 & nd & nd & nd & nd \\
\hline 633441 & nd & nd & nd & nd \\
\hline 633442 & nd & nd & nd & nd \\
\hline 633443 & nd & nd & nd & nd \\
\hline 633444 & nd & nd & nd & nd \\
\hline 633445 & nd & nd & nd & nd \\
\hline 633446 & nd & nd & nd & nd \\
\hline 633447 & nd & nd & nd & nd \\
\hline 633448 & 0.04 & nd & nd & nd \\
\hline 633449 & nd & nd & nd & nd \\
\hline 633450 & nd & nd & nd & nd \\
\hline 633451 & nd & nd & nd & nd \\
\hline 633452 & nd & nd & nd & nd \\
\hline 633453 & nd & nd & nd & nd \\
\hline 633454 & nd & nd & nd & nd \\
\hline 633455 & nd & nd & nd & nd \\
\hline 633456 & nd & nd & nd & 0.04 \\
\hline 633457 & nd & nd & nd & nd \\
\hline 633458 & nd & bdl & nd & nd \\
\hline 633459 & nd & nd & nd & nd \\
\hline 633460 & nd & nd & nd & nd \\
\hline 633461 & nd & nd & nd & nd \\
\hline 633462 & nd & nd & nd & nd \\
\hline 633463 & nd & nd & nd & nd \\
\hline 633464 & nd & nd & nd & nd \\
\hline 633465 & nd & nd & nd & nd \\
\hline 633466 & nd & nd & nd & nd \\
\hline 633467 & nd & nd & nd & nd \\
\hline method blank & nd & nd & nd & nd \\
\hline method blank & nd & nd & nd & nd \\
\hline method blank & nd & nd & nd & nd \\
\hline
\end{tabular}


Table 2. Mass of organic compounds detected in soil-gas samplers, McCoys Creek Chemical Training Area, Fort Gordon, Georgia, 2009-2010.-Continued

$[\mathrm{TPH}$, total petroleum hydrocarbon; $\mu \mathrm{g}$, microgram; BTEX, combined masses of benzene, toluene, ethylbenzene and total xylenes; $m$-, meta; $p$-, para; o-, ortho; MDL, method detection level; nd, not detected; 633465, 633466 and 633467 are trip blanks; MTBE, methyl tert-butyl ether; $\mathrm{C}_{11}, \mathrm{C}_{13}, \mathrm{C}_{15}$; combined masses of undecane, tridecane, and pentadecane; DCA, dichlorethane; TCA, trichloroethane; TCE, trichloroethylene, DCE, dichloroethylene; PCE, perchloroethylene; $\mathrm{DCB}$, dichlorobenzene; $\mathrm{CCl}_{4}$, carbon tetrachloride]

\begin{tabular}{|c|c|c|c|c|}
\hline $\begin{array}{l}\text { Sampler } \\
\text { number }\end{array}$ & $\begin{array}{c}C_{11^{\prime}}, C_{13^{\prime}} C_{15} \\
(\mu \mathrm{g})\end{array}$ & $\begin{array}{c}\text { Undecane } \\
(\mu \mathrm{g})\end{array}$ & $\begin{array}{c}\text { Tridecane } \\
(\mu \mathrm{g})\end{array}$ & $\begin{array}{c}\text { Pentadecane } \\
(\mu \mathrm{g})\end{array}$ \\
\hline MDL & & 0.04 & 0.02 & 0.02 \\
\hline 633394 & nd & nd & nd & nd \\
\hline 633395 & nd & nd & nd & nd \\
\hline 633396 & 0.00 & bdl & nd & nd \\
\hline 633397 & nd & nd & nd & nd \\
\hline 633398 & nd & nd & nd & nd \\
\hline 633399 & nd & nd & nd & nd \\
\hline 633400 & nd & nd & nd & nd \\
\hline 633401 & nd & nd & nd & nd \\
\hline 633402 & nd & nd & nd & nd \\
\hline 633403 & nd & nd & nd & nd \\
\hline 633404 & nd & nd & nd & nd \\
\hline 633405 & nd & nd & nd & nd \\
\hline 633406 & nd & nd & nd & nd \\
\hline 633407 & nd & nd & nd & nd \\
\hline 633408 & nd & nd & nd & nd \\
\hline 633409 & nd & nd & nd & nd \\
\hline 633410 & nd & nd & nd & nd \\
\hline 633411 & 0.00 & bdl & nd & nd \\
\hline 633412 & 0.79 & 0.75 & 0.04 & nd \\
\hline 633413 & nd & nd & nd & nd \\
\hline 633414 & 0.00 & bdl & nd & nd \\
\hline 633415 & nd & nd & nd & nd \\
\hline 633416 & nd & nd & nd & nd \\
\hline 633417 & nd & nd & nd & nd \\
\hline 633418 & nd & nd & nd & nd \\
\hline 633419 & nd & nd & nd & nd \\
\hline 633420 & nd & nd & nd & nd \\
\hline 633421 & nd & nd & nd & nd \\
\hline 633422 & nd & nd & nd & nd \\
\hline 633423 & nd & nd & nd & nd \\
\hline 633424 & nd & nd & nd & nd \\
\hline 633425 & nd & nd & nd & nd \\
\hline 633426 & nd & nd & nd & nd \\
\hline 633427 & nd & nd & nd & nd \\
\hline 633428 & nd & nd & nd & nd \\
\hline 633429 & nd & nd & nd & nd \\
\hline 633430 & nd & nd & nd & nd \\
\hline 633431 & nd & nd & nd & nd \\
\hline 633432 & nd & nd & nd & nd \\
\hline 633433 & nd & $\mathrm{nd}$ & nd & nd \\
\hline 633434 & nd & nd & nd & nd \\
\hline 633435 & nd & nd & nd & nd \\
\hline
\end{tabular}


Table 2. Mass of organic compounds detected in soil-gas samplers, McCoys Creek Chemical Training Area, Fort Gordon, Georgia, 2009-2010.-Continued

[TPH, total petroleum hydrocarbon; $\mu \mathrm{g}$, microgram; BTEX, combined masses of benzene, toluene, ethylbenzene and total xylenes; $m$-, meta; $p$-, para; $o$-, ortho; MDL, method detection level; nd, not detected; 633465, 633466 and 633467 are trip blanks; MTBE, methyl tert-butyl ether; $\mathrm{C}_{11}, \mathrm{C}_{13}, \mathrm{C}_{15}$; combined masses of undecane, tridecane, and pentadecane; DCA, dichlorethane; TCA, trichloroethane; TCE, trichloroethylene, DCE, dichloroethylene; PCE, perchloroethylene; $\mathrm{DCB}$, dichlorobenzene; $\mathrm{CCl}_{4}$, carbon tetrachloride]

\begin{tabular}{|c|c|c|c|c|}
\hline $\begin{array}{l}\text { Sampler } \\
\text { number }\end{array}$ & $\begin{array}{c}C_{11^{\prime}}, C_{13^{\prime}} C_{15} \\
(\mu g)\end{array}$ & $\begin{array}{c}\text { Undecane } \\
(\mu \mathrm{g})\end{array}$ & $\begin{array}{c}\text { Tridecane } \\
(\mu \mathrm{g})\end{array}$ & $\begin{array}{c}\text { Pentadecane } \\
(\mu \mathrm{g})\end{array}$ \\
\hline 633436 & nd & nd & nd & nd \\
\hline 633437 & nd & nd & nd & nd \\
\hline 633438 & nd & nd & nd & nd \\
\hline 633439 & nd & nd & nd & nd \\
\hline 633440 & nd & nd & nd & nd \\
\hline 633441 & nd & nd & nd & nd \\
\hline 633442 & nd & nd & nd & nd \\
\hline 633443 & nd & nd & nd & nd \\
\hline 633444 & nd & nd & nd & nd \\
\hline 633445 & nd & nd & nd & nd \\
\hline 633446 & nd & nd & nd & nd \\
\hline 633447 & nd & nd & nd & nd \\
\hline 633448 & nd & nd & nd & nd \\
\hline 633449 & nd & nd & nd & nd \\
\hline 633450 & nd & nd & nd & nd \\
\hline 633451 & nd & nd & nd & nd \\
\hline 633452 & nd & nd & nd & nd \\
\hline 633453 & nd & nd & nd & nd \\
\hline 633454 & nd & nd & nd & nd \\
\hline 633455 & 0.00 & nd & nd & bdl \\
\hline 633456 & 0.00 & nd & nd & bdl \\
\hline 633457 & nd & nd & nd & nd \\
\hline 633458 & 0.00 & bdl & bdl & bdl \\
\hline 633459 & 0.00 & bdl & bdl & bdl \\
\hline 633460 & nd & nd & nd & nd \\
\hline 633461 & nd & nd & nd & nd \\
\hline 633462 & nd & nd & nd & nd \\
\hline 633463 & nd & nd & nd & nd \\
\hline 633464 & 0.00 & bdl & bdl & bdl \\
\hline 633465 & nd & nd & nd & nd \\
\hline 633466 & nd & nd & nd & nd \\
\hline 633467 & nd & nd & nd & nd \\
\hline method blank & nd & nd & nd & nd \\
\hline method blank & nd & nd & nd & nd \\
\hline method blank & nd & nd & nd & nd \\
\hline
\end{tabular}


Table 2. Mass of organic compounds detected in soil-gas samplers, McCoys Creek Chemical Training Area, Fort Gordon, Georgia, 2009-2010.-Continued

[TPH, total petroleum hydrocarbon; $\mu \mathrm{g}$, microgram; BTEX, combined masses of benzene, toluene, ethylbenzene and total xylenes; $m$-, $m e t a ; p$-, para; $o$-, ortho; MDL, method detection level; nd, not detected; 633465, 633466 and 633467 are trip blanks; MTBE, methyl tert-butyl ether; $\mathrm{C}_{11}, \mathrm{C}_{13}, \mathrm{C}_{15} ;$ combined masses of undecane, tridecane, and pentadecane; DCA, dichlorethane; TCA, trichloroethane; TCE, trichloroethylene, DCE, dichloroethylene; PCE, perchloroethylene; $\mathrm{DCB}$, dichlorobenzene; $\mathrm{CCl}_{4}$, carbon tetrachloride]

\begin{tabular}{|c|c|c|c|c|c|c|c|}
\hline $\begin{array}{c}\text { Sampler } \\
\text { number }\end{array}$ & $\begin{array}{c}\text { Trimethyl } \\
\text { benzenes }(\mu \mathrm{g})\end{array}$ & $\begin{array}{c}\text { 1,2,4-Trimethyl } \\
\text { benzene ( } \mu \mathrm{g})\end{array}$ & $\begin{array}{c}\text { 1,3,5-Trimethyl } \\
\text { benzene ( } \mu \mathrm{g})\end{array}$ & $\begin{array}{c}\text { 1,1-DCA } \\
(\mu \mathrm{g})\end{array}$ & $\begin{array}{c}\text { Chloroform } \\
(\mu g)\end{array}$ & $\begin{array}{c}1,1,1-\mathrm{TCA} \\
(\mu \mathrm{g})\end{array}$ & $\begin{array}{c}1,2-D C A \\
(\mu \mathrm{g})\end{array}$ \\
\hline MDL & & 0.02 & 0.03 & 0.02 & 0.02 & 0.03 & 0.02 \\
\hline 633394 & nd & nd & nd & nd & nd & nd & nd \\
\hline 633395 & nd & nd & nd & nd & nd & nd & nd \\
\hline 633396 & nd & nd & nd & nd & nd & nd & nd \\
\hline 633397 & nd & nd & nd & nd & nd & nd & nd \\
\hline 633398 & nd & nd & nd & nd & nd & nd & nd \\
\hline 633399 & nd & nd & nd & nd & 0.06 & nd & nd \\
\hline 633400 & nd & nd & nd & nd & nd & nd & nd \\
\hline 633401 & nd & nd & nd & nd & nd & nd & nd \\
\hline 633402 & nd & nd & nd & nd & nd & nd & nd \\
\hline 633403 & nd & nd & nd & nd & nd & nd & nd \\
\hline 633404 & nd & nd & nd & nd & nd & nd & nd \\
\hline 633405 & nd & nd & nd & nd & nd & nd & nd \\
\hline 633406 & nd & nd & nd & nd & nd & nd & nd \\
\hline 633407 & nd & nd & nd & nd & nd & nd & nd \\
\hline 633408 & nd & nd & nd & nd & nd & nd & nd \\
\hline 633409 & nd & nd & nd & nd & nd & nd & nd \\
\hline 633410 & nd & nd & nd & nd & nd & nd & nd \\
\hline 633411 & 0.00 & bdl & nd & nd & nd & nd & nd \\
\hline 633412 & nd & nd & nd & nd & nd & nd & nd \\
\hline 633413 & nd & nd & nd & nd & nd & nd & nd \\
\hline 633414 & nd & nd & nd & nd & 0.12 & nd & nd \\
\hline 633415 & nd & nd & nd & nd & 0.09 & nd & nd \\
\hline 633416 & nd & nd & nd & nd & nd & nd & nd \\
\hline 633417 & nd & nd & nd & nd & nd & nd & nd \\
\hline 633418 & nd & nd & nd & nd & nd & nd & nd \\
\hline 633419 & nd & nd & nd & nd & 0.04 & nd & nd \\
\hline 633420 & nd & nd & nd & nd & nd & nd & nd \\
\hline 633421 & nd & nd & nd & nd & nd & nd & nd \\
\hline 633422 & nd & nd & nd & nd & nd & nd & nd \\
\hline 633423 & nd & nd & nd & nd & nd & nd & nd \\
\hline 633424 & nd & nd & nd & nd & nd & nd & nd \\
\hline 633425 & nd & nd & nd & nd & bdl & nd & nd \\
\hline 633426 & nd & nd & nd & nd & nd & nd & nd \\
\hline 633427 & nd & nd & nd & nd & 0.04 & nd & nd \\
\hline 633428 & nd & nd & nd & nd & 0.03 & nd & nd \\
\hline 633429 & nd & nd & nd & nd & nd & nd & nd \\
\hline 633430 & nd & nd & nd & nd & 0.22 & nd & nd \\
\hline 633431 & nd & nd & nd & nd & nd & nd & nd \\
\hline 633432 & nd & nd & nd & nd & nd & nd & nd \\
\hline 633433 & nd & nd & nd & nd & nd & nd & nd \\
\hline 633434 & nd & nd & nd & nd & nd & nd & nd \\
\hline 633435 & nd & nd & nd & nd & nd & nd & nd \\
\hline 633436 & nd & nd & nd & nd & 0.02 & nd & nd \\
\hline 633437 & nd & nd & nd & nd & nd & nd & nd \\
\hline
\end{tabular}


Table 2. Mass of organic compounds detected in soil-gas samplers, McCoys Creek Chemical Training Area, Fort Gordon, Georgia, 2009-2010.-Continued

[TPH, total petroleum hydrocarbon; $\mu \mathrm{g}$, microgram; BTEX, combined masses of benzene, toluene, ethylbenzene and total xylenes; $m$-, meta; $p$-, para; $o$-, ortho; MDL, method detection level; nd, not detected; 633465, 633466 and 633467 are trip blanks; MTBE, methyl tert-butyl ether; $\mathrm{C}_{11}, \mathrm{C}_{13}, \mathrm{C}_{15} ;$ combined masses of undecane, tridecane, and pentadecane; DCA, dichlorethane; TCA, trichloroethane; TCE, trichloroethylene, DCE, dichloroethylene; PCE, perchloroethylene; $\mathrm{DCB}$, dichlorobenzene; $\mathrm{CCl}_{4}$, carbon tetrachloride]

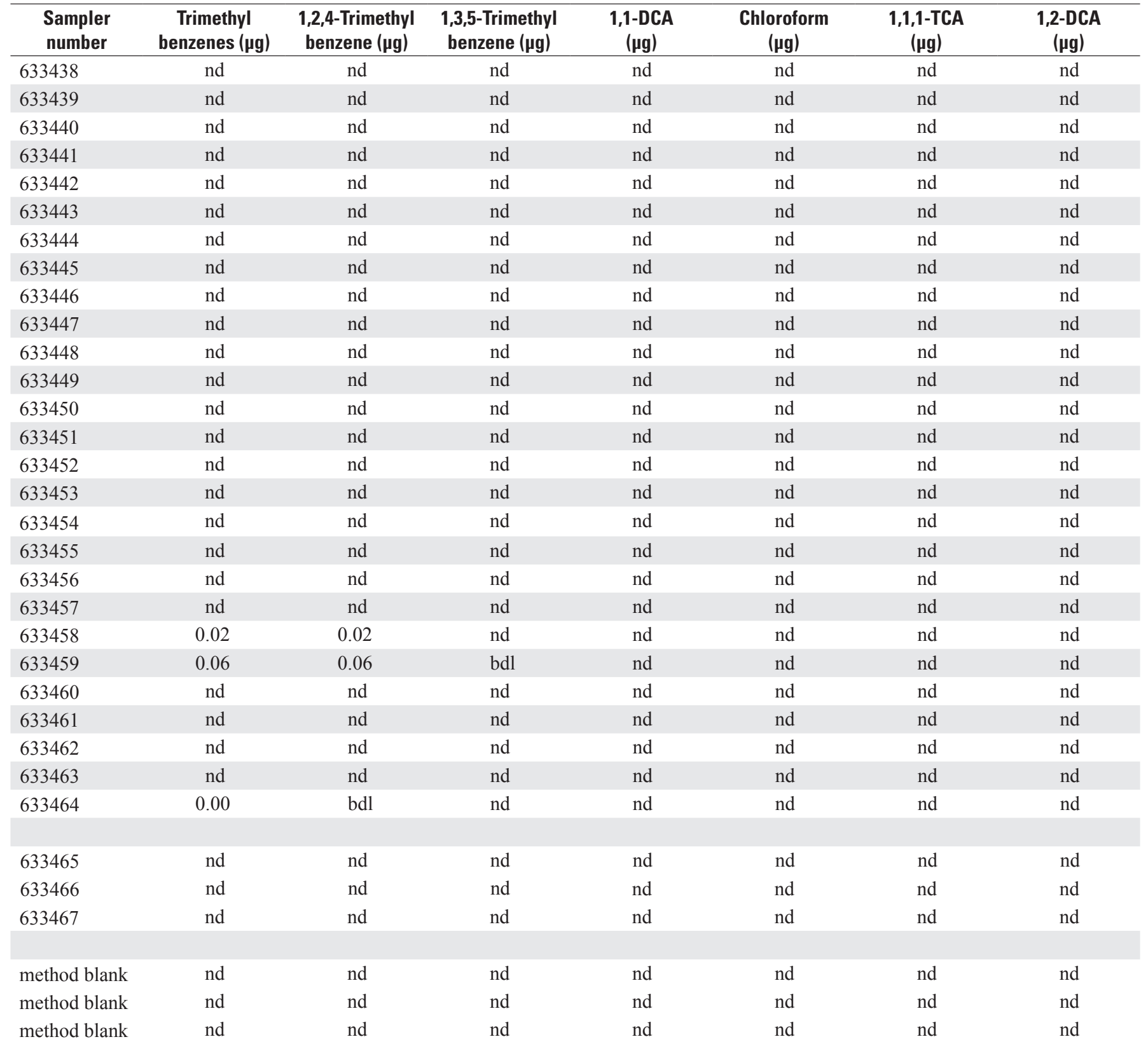


Table 2. Mass of organic compounds detected in soil-gas samplers, McCoys Creek Chemical Training Area, Fort Gordon, Georgia, 2009-2010. - Continued

[TPH, total petroleum hydrocarbon; $\mu \mathrm{g}$, microgram; BTEX, combined masses of benzene, toluene, ethylbenzene and total xylenes; $m$-, meta; $p$-, para; $o$-, ortho; MDL, method detection level; nd, not detected; 633465, 633466 and 633467 are trip blanks; MTBE, methyl tert-butyl ether; $\mathrm{C}_{11}, \mathrm{C}_{13}, \mathrm{C}_{15}$; combined masses of undecane, tridecane, and pentadecane; DCA, dichlorethane; TCA, trichloroethane; TCE, trichloroethylene, DCE, dichloroethylene; PCE, perchloroethylene; DCB, dichlorobenzene; $\mathrm{CCl}_{4}$, carbon tetrachloride]

\begin{tabular}{|c|c|c|c|c|c|}
\hline $\begin{array}{c}\text { Sampler } \\
\text { number }\end{array}$ & $\begin{array}{l}\text { TCE } \\
(\mu g)\end{array}$ & $\begin{array}{c}c-, t-1,2-D C E \\
(\mu \mathrm{g})\end{array}$ & $\begin{array}{c}t-1,2-D C E \\
(\mu g)\end{array}$ & $\begin{array}{c}c-1,2-D C E \\
(\mu \mathrm{g})\end{array}$ & $\begin{array}{l}\text { PCE } \\
(\mu g)\end{array}$ \\
\hline MDL & 0.02 & & 0.04 & 0.03 & 0.02 \\
\hline 633394 & nd & nd & nd & nd & nd \\
\hline 633395 & nd & nd & nd & nd & nd \\
\hline 633396 & nd & nd & nd & nd & nd \\
\hline 633397 & nd & nd & nd & nd & nd \\
\hline 633398 & nd & nd & nd & nd & nd \\
\hline 633399 & nd & nd & nd & nd & nd \\
\hline 633400 & nd & nd & nd & nd & nd \\
\hline 633401 & nd & nd & nd & nd & nd \\
\hline 633402 & nd & nd & nd & nd & nd \\
\hline 633403 & nd & nd & nd & nd & nd \\
\hline 633404 & nd & nd & nd & nd & nd \\
\hline 633405 & nd & nd & nd & nd & nd \\
\hline 633406 & nd & nd & nd & nd & nd \\
\hline 633407 & nd & nd & nd & nd & nd \\
\hline 633408 & nd & nd & nd & nd & nd \\
\hline 633409 & nd & nd & nd & nd & nd \\
\hline 633410 & nd & nd & nd & nd & nd \\
\hline 633411 & nd & nd & nd & nd & nd \\
\hline 633412 & nd & nd & nd & nd & nd \\
\hline 633413 & nd & nd & nd & nd & nd \\
\hline 633414 & nd & nd & nd & nd & nd \\
\hline 633415 & nd & nd & nd & nd & nd \\
\hline 633416 & nd & nd & nd & nd & nd \\
\hline 633417 & nd & nd & nd & nd & nd \\
\hline 633418 & nd & nd & nd & nd & nd \\
\hline 633419 & nd & nd & nd & nd & nd \\
\hline 633420 & nd & nd & nd & nd & nd \\
\hline 633421 & nd & nd & nd & nd & nd \\
\hline 633422 & nd & nd & nd & nd & nd \\
\hline 633423 & nd & nd & nd & nd & nd \\
\hline 633424 & nd & nd & nd & nd & nd \\
\hline 633425 & nd & nd & nd & nd & nd \\
\hline 633426 & nd & nd & nd & nd & nd \\
\hline 633427 & nd & nd & nd & nd & nd \\
\hline 633428 & nd & nd & nd & nd & 0.07 \\
\hline 633429 & nd & nd & nd & nd & nd \\
\hline 633430 & nd & nd & nd & nd & nd \\
\hline 633431 & nd & nd & nd & nd & nd \\
\hline 633432 & nd & nd & nd & nd & nd \\
\hline 633433 & nd & nd & nd & nd & nd \\
\hline 633434 & nd & nd & nd & nd & nd \\
\hline 633435 & nd & nd & nd & nd & nd \\
\hline
\end{tabular}


Table 2. Mass of organic compounds detected in soil-gas samplers, McCoys Creek Chemical Training Area, Fort Gordon, Georgia, 2009-2010. - Continued

[TPH, total petroleum hydrocarbon; $\mu \mathrm{g}$, microgram; BTEX, combined masses of benzene, toluene, ethylbenzene and total xylenes; $m$-, meta; $p$-, para; $o$-, ortho; MDL, method detection level; nd, not detected; 633465, 633466 and 633467 are trip blanks; MTBE, methyl tert-butyl ether; $\mathrm{C}_{11}, \mathrm{C}_{13}, \mathrm{C}_{15}$; combined masses of undecane, tridecane, and pentadecane; DCA, dichlorethane; TCA, trichloroethane; TCE, trichloroethylene, DCE, dichloroethylene; PCE, perchloroethylene; DCB, dichlorobenzene; $\mathrm{CCl}_{4}$, carbon tetrachloride]

\begin{tabular}{|c|c|c|c|c|c|}
\hline $\begin{array}{c}\text { Sampler } \\
\text { number }\end{array}$ & $\begin{array}{l}\text { TCE } \\
(\mu \mathrm{g}) \\
\end{array}$ & $\begin{array}{c}c-, t-1,2-D C E \\
(\mu g)\end{array}$ & $\begin{array}{c}t-1,2-D C E \\
(\mu g)\end{array}$ & $\begin{array}{c}c-1,2-D C E \\
(\mu g)\end{array}$ & $\begin{array}{l}\text { PCE } \\
(\mu g) \\
\end{array}$ \\
\hline 633436 & nd & nd & nd & nd & nd \\
\hline 633437 & nd & nd & nd & nd & nd \\
\hline 633438 & nd & nd & nd & nd & nd \\
\hline 633439 & 0.03 & nd & nd & nd & 0.12 \\
\hline 633440 & nd & nd & nd & nd & nd \\
\hline 633441 & nd & nd & nd & nd & nd \\
\hline 633442 & nd & nd & nd & nd & nd \\
\hline 633443 & nd & nd & nd & nd & nd \\
\hline 633444 & nd & nd & nd & nd & nd \\
\hline 633445 & nd & nd & nd & nd & 0.03 \\
\hline 633446 & nd & nd & nd & nd & nd \\
\hline 633447 & nd & nd & nd & nd & nd \\
\hline 633448 & nd & 0.00 & nd & bdl & nd \\
\hline 633449 & nd & nd & nd & nd & nd \\
\hline 633450 & nd & nd & nd & nd & nd \\
\hline 633451 & nd & nd & nd & nd & nd \\
\hline 633452 & nd & nd & nd & nd & nd \\
\hline 633453 & nd & nd & nd & nd & nd \\
\hline 633454 & nd & nd & nd & nd & nd \\
\hline 633455 & nd & nd & nd & nd & nd \\
\hline 633456 & nd & nd & nd & nd & nd \\
\hline 633457 & nd & nd & nd & nd & nd \\
\hline 633458 & nd & nd & nd & nd & nd \\
\hline 633459 & nd & nd & nd & nd & nd \\
\hline 633460 & nd & nd & nd & nd & nd \\
\hline 633461 & nd & nd & nd & nd & nd \\
\hline 633462 & nd & nd & nd & nd & nd \\
\hline 633463 & nd & nd & nd & nd & nd \\
\hline 633464 & nd & nd & nd & nd & nd \\
\hline 633465 & nd & nd & nd & nd & nd \\
\hline 633466 & nd & nd & nd & nd & nd \\
\hline 633467 & nd & nd & nd & nd & nd \\
\hline method blank & nd & nd & nd & nd & nd \\
\hline method blank & nd & nd & nd & nd & nd \\
\hline method blank & nd & nd & nd & nd & nd \\
\hline
\end{tabular}


Table 2. Mass of organic compounds detected in soil-gas samplers, McCoys Creek Chemical Training Area, Fort Gordon, Georgia, 2009-2010.-Continued

[TPH, total petroleum hydrocarbon; $\mu \mathrm{g}$, microgram; BTEX, combined masses of benzene, toluene, ethylbenzene and total xylenes; $m$-, meta; $p$-, para; $o$-, ortho; MDL, method detection level; nd, not detected; 633465, 633466 and 633467 are trip blanks; MTBE, methyl tert-butyl ether; $\mathrm{C}_{11}, \mathrm{C}_{13}, \mathrm{C}_{15}$; combined masses of undecane, tridecane, and pentadecane; DCA, dichlorethane; TCA, trichloroethane; TCE, trichloroethylene, DCE, dichloroethylene; PCE, perchloroethylene; DCB, dichlorobenzene; $\mathrm{CCl}_{4}$, carbon tetrachloride]

\begin{tabular}{|c|c|c|c|c|c|c|}
\hline $\begin{array}{l}\text { Sampler } \\
\text { number }\end{array}$ & $\begin{array}{c}\text { 1,4-DCB } \\
(\mu g)\end{array}$ & $\begin{array}{l}\mathrm{CCI}_{4} \\
(\mu \mathrm{g})\end{array}$ & $\begin{array}{c}1,1,2-\mathrm{TCA} \\
(\mu \mathrm{g})\end{array}$ & $\begin{array}{c}\text { Chlorobenzene } \\
(\mu \mathrm{g})\end{array}$ & $\begin{array}{c}\text { 1,1,1,2-Tetrachloro- } \\
\text { ethane }(\mu \mathrm{g})\end{array}$ & $\begin{array}{c}\text { 1,1,2,2-Tetrachloro- } \\
\text { ethane }(\mu \mathrm{g})\end{array}$ \\
\hline MDL & 0.02 & 0.03 & 0.02 & 0.02 & 0.03 & 0.02 \\
\hline 633394 & nd & nd & nd & nd & nd & nd \\
\hline 633395 & nd & nd & nd & nd & nd & nd \\
\hline 633396 & nd & nd & nd & nd & nd & nd \\
\hline 633397 & nd & nd & nd & nd & nd & nd \\
\hline 633398 & nd & nd & nd & nd & nd & nd \\
\hline 633399 & nd & nd & nd & nd & nd & nd \\
\hline 633400 & nd & nd & nd & nd & nd & nd \\
\hline 633401 & nd & nd & nd & nd & nd & nd \\
\hline 633402 & nd & nd & nd & nd & nd & nd \\
\hline 633403 & nd & nd & nd & nd & nd & nd \\
\hline 633404 & nd & nd & nd & nd & nd & nd \\
\hline 633405 & nd & nd & nd & nd & nd & nd \\
\hline 633406 & nd & nd & nd & nd & nd & nd \\
\hline 633407 & nd & nd & nd & nd & nd & nd \\
\hline 633408 & nd & nd & nd & nd & nd & nd \\
\hline 633409 & nd & nd & nd & nd & nd & nd \\
\hline 633410 & nd & nd & nd & nd & nd & nd \\
\hline 633411 & nd & nd & nd & nd & nd & nd \\
\hline 633412 & nd & nd & nd & nd & nd & nd \\
\hline 633413 & nd & nd & nd & nd & nd & nd \\
\hline 633414 & nd & nd & nd & nd & nd & nd \\
\hline 633415 & nd & nd & nd & nd & nd & nd \\
\hline 633416 & nd & nd & nd & nd & nd & nd \\
\hline 633417 & nd & nd & nd & nd & nd & nd \\
\hline 633418 & nd & nd & nd & nd & nd & nd \\
\hline 633419 & nd & nd & nd & nd & nd & nd \\
\hline 633420 & nd & nd & nd & nd & nd & nd \\
\hline 633421 & nd & nd & nd & nd & nd & nd \\
\hline 633422 & nd & nd & nd & nd & nd & nd \\
\hline 633423 & nd & nd & nd & nd & nd & nd \\
\hline 633424 & nd & nd & nd & nd & nd & nd \\
\hline 633425 & nd & nd & nd & nd & nd & nd \\
\hline 633426 & nd & nd & nd & nd & nd & nd \\
\hline 633427 & nd & nd & nd & nd & nd & nd \\
\hline 633428 & nd & nd & nd & nd & nd & nd \\
\hline 633429 & nd & nd & nd & nd & nd & nd \\
\hline 633430 & nd & nd & nd & nd & nd & nd \\
\hline 633431 & nd & nd & nd & nd & nd & nd \\
\hline 633432 & nd & nd & nd & nd & nd & nd \\
\hline 633433 & nd & nd & nd & nd & nd & nd \\
\hline 633434 & nd & nd & nd & nd & nd & nd \\
\hline 633435 & nd & nd & nd & nd & nd & nd \\
\hline 633436 & nd & nd & nd & nd & nd & nd \\
\hline
\end{tabular}


Table 2. Mass of organic compounds detected in soil-gas samplers, McCoys Creek Chemical Training Area, Fort Gordon, Georgia, 2009-2010.-Continued

[TPH, total petroleum hydrocarbon; $\mu \mathrm{g}$, microgram; BTEX, combined masses of benzene, toluene, ethylbenzene and total xylenes; $m$-, meta; $p$-, para; $o$-, ortho; MDL, method detection level; nd, not detected; 633465,633466 and 633467 are trip blanks; MTBE, methyl tert-butyl ether; $\mathrm{C}_{11}, \mathrm{C}_{13}, \mathrm{C}_{15}$; combined masses of undecane, tridecane, and pentadecane; DCA, dichlorethane; TCA, trichloroethane; TCE, trichloroethylene, DCE, dichloroethylene; PCE, perchloroethylene; $\mathrm{DCB}$, dichlorobenzene; $\mathrm{CCl}_{4}$, carbon tetrachloride]

\begin{tabular}{|c|c|c|c|c|c|c|}
\hline $\begin{array}{l}\text { Sampler } \\
\text { number }\end{array}$ & $\begin{array}{c}\text { 1,4-DCB } \\
(\mu \mathrm{g})\end{array}$ & $\begin{array}{l}\mathrm{CCI}_{4} \\
(\mu \mathrm{g})\end{array}$ & $\begin{array}{c}1,1,2-\text { TCA } \\
(\mu g)\end{array}$ & $\begin{array}{c}\text { Chlorobenzene } \\
(\mu \mathrm{g})\end{array}$ & $\begin{array}{c}1,1,1,2-\text { Tetrachloro- } \\
\text { ethane }(\mu \mathrm{g})\end{array}$ & $\begin{array}{c}1,1,2,2-\text { Tetrachloro- } \\
\text { ethane }(\mu \mathrm{g})\end{array}$ \\
\hline 633437 & nd & nd & nd & nd & nd & nd \\
\hline 633438 & nd & nd & nd & nd & nd & nd \\
\hline 633439 & nd & nd & nd & nd & nd & nd \\
\hline 633440 & nd & nd & nd & nd & nd & nd \\
\hline 633441 & nd & nd & nd & nd & nd & nd \\
\hline 633442 & nd & nd & nd & nd & nd & nd \\
\hline 633443 & nd & nd & nd & nd & nd & nd \\
\hline 633444 & nd & nd & nd & nd & nd & nd \\
\hline 633445 & nd & nd & nd & nd & nd & nd \\
\hline 633446 & nd & nd & nd & nd & nd & nd \\
\hline 633447 & nd & nd & nd & nd & nd & nd \\
\hline 633448 & nd & nd & nd & nd & nd & nd \\
\hline 633449 & 0.04 & nd & nd & nd & nd & nd \\
\hline 633450 & nd & nd & nd & nd & nd & nd \\
\hline 633451 & nd & nd & nd & nd & nd & nd \\
\hline 633452 & nd & nd & nd & nd & nd & nd \\
\hline 633453 & nd & nd & nd & nd & nd & nd \\
\hline 633454 & nd & nd & nd & nd & nd & nd \\
\hline 633455 & nd & nd & nd & nd & nd & nd \\
\hline 633456 & nd & nd & nd & nd & nd & nd \\
\hline 633457 & nd & nd & nd & nd & nd & nd \\
\hline 633458 & nd & nd & nd & nd & nd & nd \\
\hline 633459 & nd & nd & nd & nd & nd & nd \\
\hline 633460 & nd & nd & nd & nd & nd & nd \\
\hline 633461 & nd & nd & nd & nd & nd & nd \\
\hline 633462 & nd & nd & nd & nd & nd & nd \\
\hline 633463 & nd & nd & nd & nd & nd & nd \\
\hline 633464 & nd & nd & nd & nd & nd & nd \\
\hline 633465 & nd & nd & nd & nd & nd & nd \\
\hline 633466 & nd & nd & nd & nd & nd & nd \\
\hline 633467 & nd & nd & nd & nd & nd & nd \\
\hline method blank & nd & nd & nd & nd & nd & nd \\
\hline method blank & nd & nd & nd & nd & nd & nd \\
\hline method blank & nd & nd & nd & nd & nd & nd \\
\hline
\end{tabular}


Table 2. Mass of organic compounds detected in soil-gas samplers, McCoys Creek Chemical Training Area, Fort Gordon, Georgia, 20092010.-Continued

[TPH, total petroleum hydrocarbon; $\mu \mathrm{g}$, microgram; BTEX, combined masses of benzene, toluene, ethylbenzene and total xylenes; $m$-, meta; $p$-, para; $o-$, ortho; MDL, method detection level; nd, not detected; 633465, 633466 and 633467 are trip blanks; MTBE, methyl tert-butyl ether; $\mathrm{C}_{11}, \mathrm{C}_{13}, \mathrm{C}_{15}$; combined masses of undecane, tridecane, and pentadecane; DCA, dichlorethane; TCA, trichloroethane; TCE, trichloroethylene, DCE, dichloroethylene; PCE, perchloroethylene; DCB, dichlorobenzene; $\mathrm{CCl}_{4}$, carbon tetrachloride]

\begin{tabular}{|c|c|c|}
\hline $\begin{array}{c}\text { Sampler } \\
\text { number }\end{array}$ & $\begin{array}{c}\text { 1,3-Dichlorobenzene } \\
(\mu \mathrm{g})\end{array}$ & $\begin{array}{c}\text { 1,2-Dichlorobenzene } \\
(\mu \mathrm{g})\end{array}$ \\
\hline MDL & 0.02 & 0.02 \\
\hline 633394 & nd & nd \\
\hline 633395 & nd & nd \\
\hline 633396 & nd & nd \\
\hline 633397 & nd & nd \\
\hline 633398 & nd & nd \\
\hline 633399 & nd & nd \\
\hline 633400 & nd & nd \\
\hline 633401 & nd & nd \\
\hline 633402 & nd & nd \\
\hline 633403 & nd & nd \\
\hline 633404 & nd & nd \\
\hline 633405 & nd & nd \\
\hline 633406 & nd & nd \\
\hline 633407 & nd & nd \\
\hline 633408 & nd & nd \\
\hline 633409 & nd & nd \\
\hline 633410 & nd & nd \\
\hline 633411 & nd & nd \\
\hline 633412 & nd & nd \\
\hline 633413 & nd & nd \\
\hline 633414 & nd & nd \\
\hline 633415 & nd & nd \\
\hline 633416 & nd & nd \\
\hline 633417 & nd & nd \\
\hline 633418 & nd & nd \\
\hline 633419 & nd & nd \\
\hline 633420 & nd & nd \\
\hline 633421 & nd & nd \\
\hline 633422 & nd & nd \\
\hline 633423 & nd & nd \\
\hline 633424 & nd & nd \\
\hline 633425 & nd & nd \\
\hline 633426 & nd & nd \\
\hline 633427 & nd & nd \\
\hline 633428 & nd & nd \\
\hline 633429 & nd & nd \\
\hline 633430 & nd & nd \\
\hline 633431 & nd & nd \\
\hline 633432 & nd & nd \\
\hline 633433 & nd & nd \\
\hline
\end{tabular}


Table 2. Mass of organic compounds detected in soil-gas samplers, McCoys Creek Chemical Training Area, Fort Gordon, Georgia, 20092010.-Continued

[TPH, total petroleum hydrocarbon; $\mu \mathrm{g}$, microgram; BTEX, combined masses of benzene, toluene, ethylbenzene and total xylenes; $m$-, meta; $p$-, para; o-, ortho; MDL, method detection level; nd, not detected; 633465, 633466 and 633467 are trip blanks; MTBE, methyl tert-butyl ether; $\mathrm{C}_{11}, \mathrm{C}_{13}, \mathrm{C}_{15}$; combined masses of undecane, tridecane, and pentadecane; DCA, dichlorethane; TCA, trichloroethane; TCE, trichloroethylene, DCE, dichloroethylene; PCE, perchloroethylene; DCB, dichlorobenzene; $\mathrm{CCl}_{4}$, carbon tetrachloride]

\begin{tabular}{|c|c|c|}
\hline $\begin{array}{c}\text { Sampler } \\
\text { number }\end{array}$ & $\begin{array}{c}\text { 1,3-Dichlorobenzene } \\
(\mu \mathrm{g})\end{array}$ & $\begin{array}{c}\text { 1,2-Dichlorobenzene } \\
(\mu \mathrm{g})\end{array}$ \\
\hline 633434 & nd & nd \\
\hline 633435 & nd & nd \\
\hline 633436 & nd & nd \\
\hline 633437 & nd & nd \\
\hline 633438 & nd & nd \\
\hline 633439 & nd & nd \\
\hline 633440 & nd & nd \\
\hline 633441 & nd & nd \\
\hline 633442 & nd & nd \\
\hline 633443 & nd & nd \\
\hline 633444 & nd & nd \\
\hline 633445 & nd & nd \\
\hline 633446 & nd & nd \\
\hline 633447 & nd & nd \\
\hline 633448 & nd & nd \\
\hline 633449 & nd & nd \\
\hline 633450 & nd & nd \\
\hline 633451 & nd & nd \\
\hline 633452 & nd & nd \\
\hline 633453 & nd & nd \\
\hline 633454 & nd & nd \\
\hline 633455 & nd & nd \\
\hline 633456 & nd & nd \\
\hline 633457 & nd & nd \\
\hline 633458 & nd & nd \\
\hline 633459 & nd & nd \\
\hline 633460 & nd & nd \\
\hline 633461 & nd & nd \\
\hline 633462 & nd & nd \\
\hline 633463 & nd & nd \\
\hline 633464 & nd & nd \\
\hline 633465 & nd & nd \\
\hline 633466 & nd & nd \\
\hline 633467 & nd & nd \\
\hline method blank & nd & nd \\
\hline method blank & nd & nd \\
\hline method blank & nd & nd \\
\hline
\end{tabular}


Table 3. Mass of explosives and chemical agents detected in soil-gas samplers, McCoys Creek Chemical Training Area, Fort Gordon, Georgia, 2009-2010.

[ $\mu \mathrm{g}$, microgram; MDL, minimum detection limit; nd, not detected; bdl, below detection limit; $p$, para; $644252,644253,644254,644255$, and 644256 are trip blanks]

\begin{tabular}{|c|c|c|c|c|}
\hline $\begin{array}{l}\text { Sampler } \\
\text { number }\end{array}$ & $\begin{array}{c}\text { Dimethyl } \\
\text { disulfide }(\mu \mathrm{g})\end{array}$ & $\begin{array}{c}\text { Dimethyl methyl } \\
\text { phosphonate ( } \mu \mathrm{g})\end{array}$ & $\begin{array}{c}\text { 1,4-Thioxane } \\
\text { ( } \mu \mathrm{g})\end{array}$ & $\begin{array}{c}\text { Nitrobenzene } \\
(\mu \mathrm{g})\end{array}$ \\
\hline MDL & 0.10 & 0.10 & 0.10 & 0.10 \\
\hline 644220 & nd & nd & nd & nd \\
\hline 644221 & nd & nd & nd & nd \\
\hline 644222 & nd & nd & nd & nd \\
\hline 644223 & bdl & nd & nd & nd \\
\hline 644224 & nd & nd & nd & nd \\
\hline 644252 & nd & nd & nd & nd \\
\hline 644253 & nd & nd & nd & nd \\
\hline 644254 & nd & nd & nd & nd \\
\hline 644255 & nd & nd & nd & nd \\
\hline 644256 & nd & nd & nd & nd \\
\hline
\end{tabular}

Table 3. Mass of explosives and chemical agents detected in soil-gas samplers, McCoys Creek Chemical Training Area, Fort Gordon, Georgia, 2009-2010.-Continued

[ $\mu \mathrm{g}$, microgram; MDL, minimum detection limit; nd, not detected; bdl, below detection limit; p, para; 644252, 644253, 644254, 644255 , and 644256 are trip blanks]

\begin{tabular}{|c|c|c|c|c|c|}
\hline $\begin{array}{l}\text { Sampler } \\
\text { number }\end{array}$ & $\begin{array}{l}\text { Diisopropyl methyl- } \\
\text { phosphonate }(\mu \mathrm{g})\end{array}$ & $\begin{array}{c}\text { 1,4-Dithiane } \\
\text { ( } \mu \mathrm{g})\end{array}$ & $\begin{array}{c}\text { 2-Nitrotoluene } \\
(\mu \mathrm{g})\end{array}$ & $\begin{array}{c}\text { 3-Nitrotoluene } \\
(\mu \mathrm{g})\end{array}$ & $\begin{array}{c}\text { 4-Nitrotoluene } \\
(\mu \mathrm{g})\end{array}$ \\
\hline MDL & 0.10 & 0.10 & 0.10 & 0.10 & 0.10 \\
\hline 644220 & nd & nd & nd & nd & nd \\
\hline 644221 & nd & nd & nd & nd & nd \\
\hline 644222 & nd & nd & nd & nd & nd \\
\hline 644223 & nd & nd & nd & nd & nd \\
\hline 644224 & nd & nd & nd & nd & nd \\
\hline 644252 & nd & nd & nd & nd & nd \\
\hline 644253 & nd & nd & nd & nd & nd \\
\hline 644254 & nd & nd & nd & nd & nd \\
\hline 644255 & nd & nd & nd & nd & nd \\
\hline 644256 & nd & nd & nd & nd & nd \\
\hline
\end{tabular}


Table 3. Mass of explosives and chemical agents detected in soil-gas samplers, McCoys Creek Chemical Training Area, Fort Gordon, Georgia, 2009-2010.—Continued

[ $\mu \mathrm{g}$, microgram; MDL, minimum detection limit; nd, not detected; bdl, below detection limit; p, para; 644252, 644253, 644254,644255 , and 644256 are trip blanks]

\begin{tabular}{|c|c|c|c|c|}
\hline $\begin{array}{l}\text { Sampler } \\
\text { number }\end{array}$ & $\begin{array}{c}\text { Thiodiglycol } \\
\text { ( } \mu \mathrm{g})\end{array}$ & $\begin{array}{c}\text { Benzothiazole } \\
(\mu \mathrm{g})\end{array}$ & $\begin{array}{c}\text { Chloroacetophenones } \\
(\mu \mathrm{g})\end{array}$ & $\begin{array}{c}\text { p-Chlorophenyl } \\
\text { methyl sulfide }(\mu \mathrm{g})\end{array}$ \\
\hline MDL & 0.20 & 0.10 & 0.10 & 0.10 \\
\hline 644220 & nd & nd & nd & nd \\
\hline 644221 & nd & bdl & nd & nd \\
\hline 644222 & nd & bdl & bdl & bdl \\
\hline 644223 & nd & bdl & nd & nd \\
\hline 644224 & nd & bdl & bdl & bdl \\
\hline 644252 & nd & nd & nd & nd \\
\hline 644253 & nd & nd & nd & nd \\
\hline 644254 & nd & nd & nd & nd \\
\hline 644255 & nd & nd & nd & nd \\
\hline 644256 & nd & nd & nd & nd \\
\hline
\end{tabular}

Table 3. Mass of explosives and chemical agents detected in soil-gas samplers, McCoys Creek Chemical Training Area, Fort Gordon, Georgia, 2009-2010.-Continued

[ $\mu \mathrm{g}$, microgram; MDL, minimum detection limit; nd, not detected; bdl, below detection limit; p, para; 644252, 644253, 644254,644255 , and 644256 are trip blanks]

\begin{tabular}{|c|c|c|c|c|}
\hline $\begin{array}{l}\text { Sampler } \\
\text { number }\end{array}$ & $\begin{array}{c}\text { 1,3-Dinitrobenzene } \\
(\mu \mathrm{g})\end{array}$ & $\begin{array}{c}\text { 2,6-Dinitrotoluene } \\
(\mu \mathrm{g})\end{array}$ & $\begin{array}{c}\text { 2,4-Dinitrotoluene } \\
(\mu \mathrm{g})\end{array}$ & $\begin{array}{c}\text { 1,3,5-Trinitrobenzene } \\
(\mu \mathrm{g})\end{array}$ \\
\hline MDL & 0.10 & 0.10 & 0.10 & 0.10 \\
\hline 644220 & nd & nd & nd & nd \\
\hline 644221 & nd & nd & nd & nd \\
\hline 644222 & nd & nd & nd & nd \\
\hline 644223 & nd & nd & nd & nd \\
\hline 644224 & nd & nd & nd & nd \\
\hline 644252 & nd & nd & nd & nd \\
\hline 644253 & nd & nd & nd & nd \\
\hline 644254 & nd & nd & nd & nd \\
\hline 644255 & nd & nd & nd & nd \\
\hline 644256 & nd & nd & bdl & nd \\
\hline
\end{tabular}


Table 3. Mass of explosives and chemical agents detected in soil-gas samplers, McCoys Creek Chemical Training Area, Fort Gordon, Georgia, 2009-2010._Continued

[ $\mu \mathrm{g}$, microgram; MDL, minimum detection limit; nd, not detected; bdl, below detection limit; , para; $644252,644253,644254,644255$, and 644256 are trip blanks]

\begin{tabular}{lccc}
\hline $\begin{array}{c}\text { Sampler } \\
\text { number }\end{array}$ & $\begin{array}{c}\boldsymbol{p} \text {-Chlorophenyl methyl } \\
\text { sulfoxide }(\boldsymbol{\mu g})\end{array}$ & $\begin{array}{c}\boldsymbol{p} \text {-Chlorophenyl methyl } \\
\text { sulfone }(\boldsymbol{\mu g})\end{array}$ & $\begin{array}{c}\mathbf{2 , 4 , 6} \text {-Trinitrotoluene } \\
(\boldsymbol{\mu g})\end{array}$ \\
\hline MDL & $\mathbf{0 . 1 0}$ & $\mathbf{0 . 1 0}$ & $\mathbf{0 . 1 0}$ \\
644220 & nd & nd & nd \\
644221 & nd & bdl & nd \\
644222 & nd & bdl & nd \\
644223 & nd & bdl & nd \\
644224 & nd & bdl & nd \\
& & & nd \\
644252 & nd & bdl & nd \\
644253 & nd & bdl & nd \\
644254 & nd & bdl & nd \\
644255 & nd & bdl & nd \\
644256 & nd & bdl & \\
\hline
\end{tabular}


Table 4. Inorganic compounds detected in soil from land surface to 6 inches below land surface, site 1, McCoys Creek Chemical Training Area, Fort Gordon, Georgia, August 25, 2010.

[ $\mu \mathrm{g} / \mathrm{g}$, microgram per gram; USEPA RSL, U.S. Environmental Protection Agency Regional Screening Level, Industrial Soil; mg/kg, milligram per kilogram; SCDHEC, South Carolina Department of Health and Environmental Control; --, not applicable; <, less than; *, Resource Conservation and Recovery Act (RCRA) metal; $\mathrm{nr}$, not reported. Note: $1 \mu \mathrm{g} / \mathrm{g}$ is equivalent to $1 \mathrm{mg} / \mathrm{kg}$, and $1 \mathrm{mg} / \mathrm{kg}$ is equivalent to 1 part per million (ppm); selenium and mercury were not analyzed]

\begin{tabular}{|c|c|c|c|}
\hline Compound & $\begin{array}{l}\text { Result } \\
\text { ( } \mu \mathrm{g} / \mathrm{g})\end{array}$ & $\begin{array}{c}\text { USEPA }^{\mathrm{a}} \\
\text { RSL } \\
(\mathrm{mg} / \mathrm{kg})\end{array}$ & $\begin{array}{c}\text { SCDHEC }^{\mathrm{b}} \\
\text { background } \\
(\mathrm{mg} / \mathrm{kg})\end{array}$ \\
\hline Aluminum & 4,270 & 990,000 & 13,528 \\
\hline Antimony & 0.1 & 410 & -- \\
\hline Arsenic* & $<1$ & 260 & 6.1 \\
\hline Barium* & 26.8 & 190,000 & 38 \\
\hline Beryllium & 0.08 & 2,000 & 0.6 \\
\hline Bismuth & $\mathrm{nr}$ & -- & -- \\
\hline Cadmium* & $<0.007$ & 800 & 1 \\
\hline Calcium & $<100$ & -- & 699 \\
\hline Cerium & 33.1 & -- & -- \\
\hline Cesium & 0.32 & -- & -- \\
\hline Chromium* & 5.0 & $1,500,000$ & 16 \\
\hline Cobalt & 0.31 & 300 & 4 \\
\hline Copper & 2.7 & 41,000 & 9 \\
\hline Gallium & 1.6 & -- & -- \\
\hline Iron & 1,790 & 720,000 & 15,608 \\
\hline Lanthanum & 15.1 & -- & -- \\
\hline Lead* & 2.42 & 800 & 16 \\
\hline Lithium & 3.2 & 2,000 & -- \\
\hline Magnesium & 137 & -- & 988 \\
\hline Manganese & 23.1 & 23,000 & 120 \\
\hline Molybdenum & 0.1 & 5,100 & -- \\
\hline Nickel & 1.2 & 47,000 & 6 \\
\hline Niobium & 1.9 & -- & -- \\
\hline Phosphorus & 105 & -- & -- \\
\hline Potassium & 160 & -- & 856 \\
\hline Rubidium & 2.3 & -- & -- \\
\hline Scandium & 0.5 & -- & -- \\
\hline Silver* & 0.012 & 5,100 & 4 \\
\hline Sodium & 26.4 & -- & 194 \\
\hline Strontium & 7.2 & 610,000 & -- \\
\hline Thallium & $<0.08$ & -- & 4.5 \\
\hline Thorium & 6.2 & -- & -- \\
\hline Titanium & $\mathrm{nr}$ & -- & -- \\
\hline Uranium & 0.63 & -- & -- \\
\hline Vanadium & 6.1 & 5,200 & -- \\
\hline Yttrium & 2.5 & -- & -- \\
\hline Zinc & 6.1 & 310,000 & 23 \\
\hline
\end{tabular}

${ }^{a}$ U.S. Environmental Protection Agency (2009a).

${ }^{\mathrm{b}}$ South Carolina Department of Health and Environmental Control (2002). 
Table 5. Inorganic compounds detected in soil from land surface to 6 inches below land surface, site 2, McCoys Creek Chemical Training Area, Fort Gordon, Georgia, August 25, 2010.

[ $\mu \mathrm{g} / \mathrm{g}$, microgram per gram; USEPA RSL, U.S. Environmental Protection Agency Regional Screening Level, Industrial Soil; mg/kg, milligram per kilogram; SCDHEC, South Carolina Department of Health and Environmental Control; 78,700, higher than SC background; --, not applicable; *, Resource Conservation and Recovery Act (RCRA) metal; $\mathrm{nr}$, not reported. Note: $1 \mu \mathrm{g} / \mathrm{g}$ is equivalent to $1 \mathrm{mg} / \mathrm{kg}$, and $1 \mathrm{mg} / \mathrm{kg}$ is equivalent to 1 part per million (ppm); selenium and mercury were not analyzed]

\begin{tabular}{|c|c|c|c|}
\hline Compound & $\begin{array}{l}\text { Result } \\
(\mu \mathrm{g} / \mathrm{g})\end{array}$ & $\begin{array}{c}\text { USEPA }^{\text {a }} \\
\text { RSL } \\
(\mathrm{mg} / \mathrm{kg})\end{array}$ & $\begin{array}{c}\text { SCDHEC }^{\mathrm{b}} \\
\text { Background } \\
\text { (mg/kg) }\end{array}$ \\
\hline Aluminum & 78,700 & 990,000 & 13,528 \\
\hline Antimony & 0.64 & 410 & -- \\
\hline Arsenic* & 9.3 & 260 & 6.1 \\
\hline Barium* & 142 & 190,000 & 38 \\
\hline Beryllium & 0.68 & 2,000 & 0.6 \\
\hline Bismuth & $\mathrm{nr}$ & -- & -- \\
\hline Cadmium* & 0.01 & 800 & 1 \\
\hline Calcium & 278 & -- & 699 \\
\hline Cerium & 135 & -- & -- \\
\hline Cesium & 1.1 & -- & -- \\
\hline Chromium* & 155 & $1,500,000$ & 16 \\
\hline Cobalt & 1.6 & 300 & 4 \\
\hline Copper & 16.3 & 41,000 & 9 \\
\hline Gallium & 18.2 & -- & -- \\
\hline Iron & 24,000 & 720,000 & 15,608 \\
\hline Lanthanum & 60 & -- & -- \\
\hline Lead* & 20.5 & 800 & 16 \\
\hline Lithium & 8.1 & 2,000 & -- \\
\hline Magnesium & 482 & -- & 988 \\
\hline Manganese & 47.4 & 23,000 & 120 \\
\hline Molybdenum & 1.4 & 5,100 & -- \\
\hline Nickel & 9.9 & 47,000 & 6 \\
\hline Niobium & 8.5 & -- & -- \\
\hline Phosphorus & 471 & -- & -- \\
\hline Potassium & 1,550 & -- & 856 \\
\hline Rubidium & 9.7 & -- & -- \\
\hline Scandium & 16.6 & -- & -- \\
\hline Silver* & 0.046 & 5,100 & 4 \\
\hline Sodium & 143 & -- & 194 \\
\hline Strontium & 67.6 & 610,000 & -- \\
\hline Thallium & 0.09 & -- & 4.5 \\
\hline Thorium & 12.7 & -- & -- \\
\hline Titanium & $\mathrm{nr}$ & -- & -- \\
\hline Uranium & 2.8 & -- & -- \\
\hline Vanadium & 131 & 5,200 & -- \\
\hline Yttrium & 14.7 & -- & -- \\
\hline Zinc & 21.2 & 310,000 & 23 \\
\hline
\end{tabular}

${ }^{a}$ U.S. Environmental Protection Agency (2009a).

${ }^{\mathrm{b}}$ South Carolina Department of Health and Environmental Control (2002). 
Table 6. Inorganic compounds detected in soil from land surface to 6 inches below land surface, site 3, McCoys Creek Chemical Training Area, Fort Gordon, Georgia, August 25, 2010.

[ $\mu \mathrm{g} / \mathrm{g}$, microgram per gram; USEPA RSL, U.S. Environmental Protection Agency Regional Screening Level, Industrial Soil; mg/kg, milligram per kilogram; SCDHEC, South Carolina Department of Health and Environmental Control; 41,800, higher than SC background; --, not applicable; *, Resource Conservation and Recovery Act (RCRA) metal; nr, not reported; <, less than. Note: $1 \mu \mathrm{g} / \mathrm{g}$ is equivalent to $1 \mathrm{mg} / \mathrm{kg}$, and $1 \mathrm{mg} / \mathrm{kg}$ is equivalent to 1 part per million (ppm); selenium and mercury were not analyzed]

\begin{tabular}{|c|c|c|c|}
\hline Compound & $\begin{array}{l}\text { Result } \\
(\mu \mathrm{g} / \mathrm{g})\end{array}$ & $\begin{array}{c}\text { USEPA }^{\mathrm{a}} \\
\text { RSL } \\
(\mathrm{mg} / \mathrm{kg})\end{array}$ & $\begin{array}{c}\text { SCDHEC }^{\text {b }} \\
\text { background } \\
(\mathrm{mg} / \mathrm{kg})\end{array}$ \\
\hline Aluminum & 41,800 & 990,000 & 13,528 \\
\hline Antimony & 0.3 & 410 & -- \\
\hline Arsenic* & 5.2 & 260 & 6.1 \\
\hline Barium* & 110 & 190,000 & 38 \\
\hline Beryllium & 0.38 & 2,000 & 0.6 \\
\hline Bismuth & $\mathrm{nr}$ & -- & -- \\
\hline Cadmium* & 0.008 & 800 & 1 \\
\hline Calcium & 159 & -- & 699 \\
\hline Cerium & 89.7 & -- & -- \\
\hline Cesium & 0.59 & -- & -- \\
\hline Chromium* & 65.3 & $1,500,000$ & 16 \\
\hline Cobalt & 0.8 & 300 & 4 \\
\hline Copper & 10.6 & 41,000 & 9 \\
\hline Gallium & 9.2 & -- & -- \\
\hline Iron & 12,400 & 720,000 & 15,608 \\
\hline Lanthanum & 35.7 & -- & -- \\
\hline Lead* & 11.7 & 800 & 16 \\
\hline Lithium & 7.1 & 2,000 & -- \\
\hline Magnesium & 278 & -- & 988 \\
\hline Manganese & 21.5 & 23,000 & 120 \\
\hline Molybdenum & 0.66 & 5,100 & -- \\
\hline Nickel & 5.9 & 47,000 & 6 \\
\hline Niobium & 3.8 & -- & -- \\
\hline Phosphorus & 333 & -- & -- \\
\hline Potassium & 593 & -- & 856 \\
\hline Rubidium & 4.5 & -- & -- \\
\hline Scandium & 9 & -- & -- \\
\hline Silver* & 0.019 & 5,100 & 4 \\
\hline Sodium & 59 & -- & 194 \\
\hline Strontium & 43.4 & 610,000 & -- \\
\hline Thallium & $<0.08$ & -- & 4.5 \\
\hline Thorium & 7.52 & -- & -- \\
\hline Titanium & $\mathrm{nr}$ & -- & -- \\
\hline Uranium & 2.1 & -- & -- \\
\hline Vanadium & 62.9 & 5,200 & -- \\
\hline Yttrium & 9.8 & - & -- \\
\hline Zinc & 13.5 & 310,000 & 23 \\
\hline
\end{tabular}

${ }^{a}$ U.S. Environmental Protection Agency (2009a).

${ }^{\mathrm{b}}$ South Carolina Department of Health and Environmental Control (2002). 
Table 7. Inorganic compounds detected in soil from land surface to 6 inches below land surface, site 4, McCoys Creek Chemical Training Area, Fort Gordon, Georgia, August 25, 2010.

[ $\mu \mathrm{g} / \mathrm{g}$, microgram per gram; USEPA RSL, U.S. Environmental Protection Agency Regional Screening Level, Industrial Soil; mg/kg, milligram per kilogram; SCDHEC, South Carolina Department of Health and Environmental Control; --, not applicable; *, Resource Conservation and Recovery Act (RCRA) metal; <, less than; 54.7, higher than SC background; nr, not reported. Note: $1 \mu \mathrm{g} / \mathrm{g}$ is equivalent to $1 \mathrm{mg} / \mathrm{kg}$, and $1 \mathrm{mg} / \mathrm{kg}$ is equivalent to 1 part per million (ppm); selenium and mercury were not analyzed]

\begin{tabular}{|c|c|c|c|}
\hline Compound & $\begin{array}{l}\text { Result } \\
(\mu \mathrm{g} / \mathrm{g})\end{array}$ & $\begin{array}{c}\text { USEPA }^{\mathrm{a}} \\
\mathrm{RSL} \\
(\mathrm{mg} / \mathrm{kg})\end{array}$ & $\begin{array}{c}\text { SCDHEC }^{b} \\
\text { background } \\
\text { (mg/kg) }\end{array}$ \\
\hline Aluminum & 9,320 & 990,000 & 13,528 \\
\hline Antimony & 0.01 & 410 & -- \\
\hline Arsenic* & $<1$ & 260 & 6.1 \\
\hline Barium* & 54.7 & 190,000 & 38 \\
\hline Beryllium & 0.16 & 2,000 & 0.6 \\
\hline Bismuth & $\mathrm{nr}$ & -- & -- \\
\hline Cadmium* & 0.01 & 800 & 1 \\
\hline Calcium & 131 & -- & 699 \\
\hline Cerium & 26.1 & -- & -- \\
\hline Cesium & 0.73 & -- & -- \\
\hline Chromium* & 12.3 & $1,500,000$ & 16 \\
\hline Cobalt & 0.91 & 300 & 4 \\
\hline Copper & 4.5 & 41,000 & 9 \\
\hline Gallium & 2.5 & -- & -- \\
\hline Iron & 3,820 & 720,000 & 15,608 \\
\hline Lanthanum & 11.8 & -- & -- \\
\hline Lead* & 3.45 & 800 & 16 \\
\hline Lithium & 5.3 & 2,000 & -- \\
\hline Magnesium & 330 & -- & 988 \\
\hline Manganese & 310 & 23,000 & 120 \\
\hline Molybdenum & 0.2 & 5,100 & -- \\
\hline Nickel & 2.5 & 47,000 & 6 \\
\hline Niobium & 3 & -- & -- \\
\hline Phosphorus & 135 & -- & -- \\
\hline Potassium & 613 & -- & 856 \\
\hline Rubidium & 8 & -- & -- \\
\hline Scandium & 1.3 & -- & -- \\
\hline Silver* & 0.014 & 5,100 & 4 \\
\hline Sodium & 80.6 & -- & 194 \\
\hline Strontium & 7.4 & 610,000 & -- \\
\hline Thallium & $<0.08$ & -- & 4.5 \\
\hline Thorium & 3.54 & -- & -- \\
\hline Titanium & $\mathrm{nr}$ & -- & -- \\
\hline Uranium & 0.71 & -- & -- \\
\hline Vanadium & 14.8 & 5,200 & -- \\
\hline Yttrium & 4.4 & -- & -- \\
\hline Zinc & 10.1 & 310,000 & 23 \\
\hline
\end{tabular}

${ }^{a}$ U.S. Environmental Protection Agency (2009a).

${ }^{\mathrm{b}}$ South Carolina Department of Health and Environmental Control (2002). 
Table 8. Inorganic compounds detected in soil from land surface to 6 inches below land surface, site 5, McCoys Creek Chemical Training Area, Fort Gordon, Georgia, August 25, 2010.

$[\mu \mathrm{g} / \mathrm{g}$, microgram per gram; USEPA RSL, U.S. Environmental Protection Agency Regional Screening Level, Industrial Soil; mg/kg, milligram per kilogram; SCDHEC, South Carolina Department of Health and Environmental Control; --, not applicable; *, Resource Conservation and Recovery Act (RCRA) metal; <, less than; 51.3, higher than SC background; nr, not reported. Note: $1 \mu \mathrm{g} / \mathrm{g}$ is equivalent to $1 \mathrm{mg} / \mathrm{kg}$, and $1 \mathrm{mg} / \mathrm{kg}$ is equivalent to 1 part per million (ppm); selenium and mercury were not analyzed]

\begin{tabular}{|c|c|c|c|}
\hline Compound & $\begin{array}{l}\text { Result } \\
(\mu \mathrm{g} / \mathrm{g})\end{array}$ & $\begin{array}{c}\text { USEPA }^{a} \\
\text { RSL } \\
(\mathrm{mg} / \mathrm{kg})\end{array}$ & $\begin{array}{c}\text { SCDHEC }^{b} \\
\text { background } \\
\text { (mg/kg) }\end{array}$ \\
\hline Aluminum & 4,860 & 990,000 & 13,528 \\
\hline Antimony & 0.01 & 410 & -- \\
\hline Arsenic* & $<1$ & 260 & 6.1 \\
\hline Barium* & 51.3 & 190,000 & 38 \\
\hline Beryllium & 0.13 & 2,000 & 0.6 \\
\hline Bismuth & $\mathrm{nr}$ & -- & -- \\
\hline Cadmium* & $<0.007$ & 800 & 1 \\
\hline Calcium & 101 & -- & 699 \\
\hline Cerium & 25.9 & -- & -- \\
\hline Cesium & 0.49 & -- & -- \\
\hline Chromium* & 7.6 & $1,500,000$ & 16 \\
\hline Cobalt & 0.63 & 300 & 4 \\
\hline Copper & 3.4 & 41,000 & 9 \\
\hline Gallium & 1.6 & -- & -- \\
\hline Iron & 1,840 & 720,000 & 15,608 \\
\hline Lanthanum & 11.3 & -- & -- \\
\hline Lead* & 1.99 & 800 & 16 \\
\hline Lithium & 2 & 2,000 & -- \\
\hline Magnesium & 143 & -- & 988 \\
\hline Manganese & 54.4 & 23,000 & 120 \\
\hline Molybdenum & 0.1 & 5,100 & -- \\
\hline Nickel & 1.4 & 47,000 & 6 \\
\hline Niobium & 2.4 & -- & -- \\
\hline Phosphorus & 98.4 & -- & -- \\
\hline Potassium & 382 & -- & 856 \\
\hline Rubidium & 3.8 & -- & -- \\
\hline Scandium & 0.8 & -- & -- \\
\hline Silver* & 0.014 & 5,100 & 4 \\
\hline Sodium & 58.8 & -- & 194 \\
\hline Strontium & 8.6 & 610,000 & -- \\
\hline Thallium & $<0.08$ & -- & 4.5 \\
\hline Thorium & 3.8 & -- & -- \\
\hline Titanium & $\mathrm{nr}$ & -- & -- \\
\hline Uranium & 0.78 & -- & -- \\
\hline Vanadium & 7.7 & 5,200 & -- \\
\hline Yttrium & 8.3 & -- & -- \\
\hline Zinc & 7.3 & 310,000 & 23 \\
\hline
\end{tabular}

${ }^{\text {a }}$ U.S. Environmental Protection Agency (2009a).

${ }^{\mathrm{b}}$ South Carolina Department of Health and Environmental Control (2002). 
Table 9. Organic compounds detected in McCoys Creek, McCoys Creek Chemical Training Area, Fort Gordon, Georgia, September 8, 2010.

$[\mu \mathrm{g} / \mathrm{L}$, microgram per liter; MCL, maximum contaminant level for National Primary Drinking Water Standards (NPDWS); $<$, less than the indicated laboratory reporting limit; -, not applicable; E, estimated; $c, c i s ; m$, meta; $p$, para, $n$, normal; o, ortho]

\begin{tabular}{|c|c|c|}
\hline Compound & $\begin{array}{l}\text { Result } \\
\text { ( } \mu \mathrm{g} / \mathrm{L})\end{array}$ & $\begin{array}{l}M C^{a} \\
(\mu g / L)\end{array}$ \\
\hline 1,1,1,2-Tetrachloroethane & $<0.04$ & - \\
\hline 1,1,1-Trichloroethane & $<0.03$ & 200 \\
\hline 1,1,2,2-Tetrachloroethane & $<0.14$ & - \\
\hline 1,1,2-Trichloroethane & $<0.046$ & 5 \\
\hline 1,1,2-Trichlorotrifluoroethane & $<0.034$ & - \\
\hline 1,1-Dichloroethane & $<0.044$ & - \\
\hline 1,1-Dichloroethylene & $<0.022$ & 7 \\
\hline 1,1-Dichloropropene & $<0.03$ & - \\
\hline 1,2,3,4-Tetramethylbenzene & $<0.08$ & - \\
\hline 1,2,3,5-Tetramethylbenzene & $<0.08$ & - \\
\hline 1,2,3-Trichlorobenzene & $<0.06$ & - \\
\hline 1,2,3-Trichloropropane & $<0.12$ & - \\
\hline 1,2,3-Trimethylbenzene & $<0.06$ & - \\
\hline 1,2,4-Trichlorobenzene & $<0.08$ & 70 \\
\hline 1,2,4-Trimethylbenzene & $<0.032$ & - \\
\hline 1,2-Dibromo-3-chloropropane & $<0.34$ & 0.2 \\
\hline 1,2-Dibromoethane & $<0.05$ & - \\
\hline 1,2-Dichlorobenzene & $<0.028$ & 600 \\
\hline 1,2-Dichloroethane & $<0.08$ & 5 \\
\hline 1,2-Dichloropropane & $<0.026$ & 5 \\
\hline 1,3,5-Trimethylbenzene & $<0.032$ & - \\
\hline 1,3-Dichlorobenzene & $<0.024$ & - \\
\hline 1,3-Dichloropropane & $<0.06$ & - \\
\hline 1,4-Dichlorobenzene & $<0.026$ & 75 \\
\hline 2,2-Dichloropropane & $<0.06$ & - \\
\hline 2-Butanone & $<1.6$ & - \\
\hline 2-Chlorotoluene & $<0.028$ & - \\
\hline 2-Hexanone & $<0.46$ & - \\
\hline 3-Chloropropene & $<0.08$ & - \\
\hline 4-Chlorotoluene & $<0.042$ & - \\
\hline 4-Isopropyl-1-methylbenzene & $<0.06$ & - \\
\hline 4-Methyl-2-pentanone & $<0.32$ & - \\
\hline Acetone & $1.09(\mathrm{E})$ & - \\
\hline Acrylonitrile & $<0.8$ & - \\
\hline Benzene & $<0.026$ & 5 \\
\hline Bromobenzene & $<0.022$ & - \\
\hline Bromochloromethane & $<0.06$ & - \\
\hline Bromodichloromethane & $<0.034$ & - \\
\hline Bromoethene & $<0.12$ & - \\
\hline Bromoform & $<0.1$ & - \\
\hline Bromomethane & $<0.2$ & - \\
\hline Butylbenzene & $<0.08$ & - \\
\hline carbon disulfide & $<0.04$ & - \\
\hline Chlorobenzene & $<0.016$ & 100 \\
\hline Chloroethane & $<0.06$ & - \\
\hline
\end{tabular}


Table 9. Organic compounds detected in McCoys Creek, McCoys Creek Chemical Training Area, Fort Gordon, Georgia, September 8, 2010.-Continued

$[\mu \mathrm{g} / \mathrm{L}$, microgram per liter; MCL, maximum contaminant level for National Primary Drinking Water Standards (NPDWS); $<$, less than the indicated laboratory reporting limit; -, not applicable; E, estimated; $c$, cis; $m$, meta; $p$, para, $n$, normal; o, ortho]

\begin{tabular}{|c|c|c|}
\hline Compound & $\begin{array}{c}\text { Result } \\
\text { ( } \mu \mathrm{g} / \mathrm{L})\end{array}$ & $\begin{array}{l}\mathrm{MCL}^{\mathrm{a}} \\
(\mu \mathrm{g} / \mathrm{L})\end{array}$ \\
\hline Chloroform & $<0.0737$ & - \\
\hline Chloromethane & $<0.14$ & - \\
\hline cis-1,2-Dichloroethylene & $<0.022$ & 70 \\
\hline cis-1,3-Dichloropropene & $<0.1$ & - \\
\hline Dibromochloromethane & $<0.12$ & - \\
\hline Dibromomethane & $<0.05$ & - \\
\hline Dichlorodifluoromethane & $<0.1$ & - \\
\hline Dichloromethane & $<0.038$ & - \\
\hline Diethyl ether & $<0.08$ & - \\
\hline Diisopropyl ether & $<0.06$ & - \\
\hline Ethyl methacrylate & $<0.14$ & - \\
\hline Ethyl tert-butyl ether & $<0.032$ & - \\
\hline Ethylbenzene & $<0.036$ & 700 \\
\hline Hexachlorobutadiene & $<0.06$ & - \\
\hline Hexachloroethane & $<0.14$ & - \\
\hline Isopropylbenzene & $<0.042$ & - \\
\hline$m$ - and $p$-Xylene & $<0.08$ & $10,000^{b}$ \\
\hline Methyl acrylate & $<0.56$ & - \\
\hline Methyl acrylonitrile & $<0.26$ & - \\
\hline Methyl iodide & $<0.26$ & - \\
\hline Methyl methacrylate & $<0.22$ & - \\
\hline$n$-Propylbenzene & $<0.036$ & - \\
\hline Napthelene & $<0.18$ & \\
\hline$o$-Ethyl toluene & $<0.032$ & - \\
\hline$o$-Xylene & $<0.032$ & $10,000^{\mathrm{b}}$ \\
\hline sec-Butylbenzene & $<0.034$ & - \\
\hline Styrene & $<0.03$ & 100 \\
\hline tert-Butyl methyl ether & $<0.1$ & - \\
\hline tert-Butylbenzene & $<0.06$ & - \\
\hline tert-Pentyl methyl ether & $<0.06$ & - \\
\hline Tetrachloroethylene & $<0.026$ & - \\
\hline Tetrachloromethane & $<0.052$ & - \\
\hline Tetrahydrofuran & $<1.4$ & - \\
\hline Toluene & $<0.018$ & 1,000 \\
\hline trans-1,2-Dichloroethylene & $<0.018$ & 100 \\
\hline trans-1,3-Dichloropropene & $<0.14$ & - \\
\hline trans-1,4-Dichloro-2-butene & $<0.36$ & - \\
\hline Trichloroethylene & $0.0181(\mathrm{E})$ & 5 \\
\hline Trichlorofluoromethane & $<0.08$ & - \\
\hline Vinyl chloride & $<0.06$ & 2 \\
\hline
\end{tabular}

${ }^{a}$ U.S. Environmental Protection Agency (2009b)

${ }^{b}$ The maximum contaminant level for the National Primary Drinking Water Regulations for total xylene (the summation of para-, meta-, and ortho-xylene) 
Table 10. Semivolatile organic compounds detected in McCoys Creek, McCoys Creek Chemical Training Area, Fort Gordon, Georgia, September 8, 2010.

$[\mu \mathrm{g} / \mathrm{L}$, microgram per liter; $\mathrm{MCL}$, maximum contaminant level; $<$, less than the indicated laboratory reporting level; $n$, normal]

\begin{tabular}{|c|c|c|}
\hline Compound & $\begin{array}{l}\text { Result } \\
\text { ( } \mu \mathrm{g} / \mathrm{L})\end{array}$ & $\begin{array}{l}M C^{a} \\
(\mu g / L)\end{array}$ \\
\hline 1,2-Dichlorobenzene & $<0.20$ & 600 \\
\hline 1, 3-Dichlorobenzene & $<0.22$ & \\
\hline 1, 4 Dichlorobenzene & $<0.22$ & 75 \\
\hline 1,2-Diphenylhydrazine & $<0.3$ & \\
\hline 1, 2 4-Trichlorobenzene & $<0.26$ & 70 \\
\hline 2,4,6-Trichlorophenol & $<0.34$ & \\
\hline 2,4-Dichlorophenol & $<0.36$ & \\
\hline 2,4-Dimethylphenol & $<0.8$ & \\
\hline 2,4-Dinitrophenol & $<1.4$ & \\
\hline 2,4-Dinitrotoluene & $<0.56$ & \\
\hline 2,6-Dinitrotoluene & $<0.4$ & \\
\hline 2-Chloronaphthalene & $<0.16$ & \\
\hline 2-Chlorophenol & $<0.26$ & \\
\hline 2-Nitrophenol & $<0.4$ & \\
\hline 3,3-Dichlorobenzidine & $<0.42$ & \\
\hline 4,6-Dinitro-2-methylphenol & $<0.76$ & \\
\hline 4-Bromophenylphenylether & $<0.24$ & \\
\hline 4-Chloro-3-methylphenol & $<0.55$ & \\
\hline 4-Chlorophenyl phenyl ether & $<0.34$ & \\
\hline 4-Nitrophenol & $<0.51$ & \\
\hline Acenaphthene & $<0.28$ & \\
\hline Acenaphthylene & $<0.3$ & \\
\hline Anthracene & $<0.39$ & \\
\hline Benz[a]anthracene & $<0.26$ & \\
\hline Benzo[a]pyrene & $<0.33$ & 0.2 \\
\hline Benzo[b]fluoranthene, & $<0.3$ & \\
\hline Benzo[ghi]perylene & $<0.38$ & \\
\hline Benzo[k]fluoranthene & $<0.3$ & \\
\hline bis(2-Chloroethoxy)methane & $<0.24$ & \\
\hline bis(2-Chloroethyl)ether & $<0.3$ & \\
\hline bis(2-Chloroisopropyl) ether & $<0.14$ & \\
\hline bis(2-Ethylhexyl) phthalate & $<2$ & \\
\hline Butylbenzyl phthalate & $<1.8$ & \\
\hline Chrysene & $<0.33$ & \\
\hline dibenz $[\mathrm{a}, \mathrm{h}]$ Anthracene & $<0.42$ & \\
\hline diethyl Phthalate & $<0.61$ & \\
\hline dimethyl Phthalate & $<0.36$ & \\
\hline di- $n$-Butyl phthalate & $<2$ & \\
\hline di- $n$-Octyl phthalate & $<0.6$ & \\
\hline Fluoranthene & $<0.3$ & \\
\hline Fluorine & $<0.33$ & \\
\hline Hexachlorobutadiene & $<0.24$ & \\
\hline Hexachlorobenzene & $<0.3$ & 1 \\
\hline Hexachloroethane & $<0.24$ & \\
\hline Hexachlorocyclopentadiene & $<0.5$ & 50 \\
\hline
\end{tabular}


Table 10. Semivolatile organic compounds detected in McCoys Creek, McCoys Creek Chemical Training Area, Fort Gordon, Georgia, September 8, 2010.-Continued

$[\mu \mathrm{g} / \mathrm{L}$, microgram per liter; $\mathrm{MCL}$, maximum contaminant level; $<$, less than the indicated laboratory reporting level; $n$, normal]

\begin{tabular}{lcc}
\hline \multicolumn{1}{c}{ Compound } & $\begin{array}{c}\text { Result } \\
(\boldsymbol{\mu} \mathbf{g} / \mathbf{L})\end{array}$ & $\begin{array}{c}\mathbf{M C L}^{\mathbf{a}} \\
(\boldsymbol{\mu g} / \mathbf{L})\end{array}$ \\
\hline Isophorone & $<0.26$ & \\
\hline Indeno[1,2,3-cd]pyrene & $<0.38$ & \\
Naphthalene & $<0.22$ & \\
Nitrobenzene & $<0.26$ & \\
n-Nitrosodimethylamine & $<0.24$ & \\
\hline n-Nitrosodi-n-propylamine & $<0.4$ & \\
\hline$n$-Nitrosodiphenylamine & $<0.28$ \\
\hline Pentachlorophenol & $<0.6$ & \\
\hline Phenanthrene & $<0.32$ \\
\hline Phenol & $<0.28$ \\
\hline Pyrene & $<0.35$ & \\
\hline
\end{tabular}

${ }^{\mathrm{a}}$ U.S. Environmental Protection Agency (2009b). 
Table 11. Inorganic compounds detected in McCoys Creek, McCoys Creek Chemical Training Area, Fort Gordon, Georgia, September 8, 2010.

$[\mu \mathrm{g} / \mathrm{L}$, micrograms per liter; ISWQS, Georgia In-Stream Water-Quality Standard, acute freshwater; MCL, Maximum Contaminant Level for National Primary Drinking Water Standards (NPDWS); SMCL, Maximum

Contaminant Level for National Secondary Drinking Water Standards (NSDWS); E, estimated; 578, exceedance;

*, Resource Conservation and Recovery Act (RCRA) metal; --, not applicable]

\begin{tabular}{|c|c|c|c|c|}
\hline Compound & $\begin{array}{l}\text { Result } \\
\text { ( } \mu \mathrm{g} / \mathrm{L})\end{array}$ & $\begin{array}{c}\text { ISWOS }^{a} \\
\text { ( } \mu \mathrm{g} / \mathrm{L})\end{array}$ & $\begin{array}{l}\text { MCL } \\
\text { ( } \mu \mathrm{g} / \mathrm{L})\end{array}$ & $\begin{array}{l}\text { SMCL } \\
(\mu \mathrm{g} / \mathrm{L})\end{array}$ \\
\hline Aluminum & 35.4 & -- & -- & 50 to 200 \\
\hline Arsenic * & 0.311 & 340 & 10 & -- \\
\hline Barium * & 21.7 & -- & 2,000 & -- \\
\hline Beryllium & $<0.38$ & -- & 4 & -- \\
\hline Cadmium * & $0.030(\mathrm{E})$ & $2^{c}$ & 5 & -- \\
\hline Calcium & 1.15 & -- & -- & -- \\
\hline Chromium * & $<0.42$ & $320^{\mathrm{c}}$ & 100 & -- \\
\hline Cobalt & 0.23 & -- & -- & -- \\
\hline Copper & $<3.8$ & $7^{\mathrm{c}}$ & -- & 1,000 \\
\hline Iron & 578 & -- & -- & 300 \\
\hline Lead * & 0.193 & $30^{c}$ & $15^{\mathrm{d}}$ & -- \\
\hline Lithium & 0.683 & -- & -- & -- \\
\hline Magnesium & 0.723 & -- & -- & -- \\
\hline Manganese & 10.2 & -- & -- & 50 \\
\hline Molybdenum & $<0.1$ & -- & -- & -- \\
\hline Nickel & 0.42 & $260^{c}$ & -- & -- \\
\hline Potassium & 0.457 & -- & -- & -- \\
\hline Selenium * & 0.166 & -- & 50 & -- \\
\hline Silver * & $<0.016$ & -- & -- & 100 \\
\hline Sodium & 1.72 & -- & -- & -- \\
\hline Strontium & 9.19 & -- & -- & -- \\
\hline Zinc & 4.9 & $65^{c}$ & & 5,000 \\
\hline
\end{tabular}


Manuscript approved on August 31, 2011.

\section{Prepared by:}

USGS Science Publishing Network

Raleigh Publishing Service Center

3916 Sunset Ridge Road

Raleigh, NC 27607

For additional information regarding this publication, contact: Director

USGS South Carolina Water Science Center

720 Gracern Road, Suite 129

Columbia, SC 29210

phone: 803-750-6100

e-mail:dc_sc@usgs.gov

Or visit the South Carolina Water Science Center Web site at: http://sc.water.usgs.gov

A PDF version of this publication is available online at http://pubs.usgs.gov/of/2011/1267/ 


\section{๕}

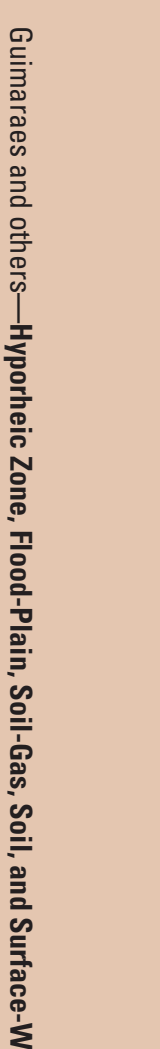

\section{.}

